\title{
O NIEKTÓRYCH MITACH, NIEŚCISŁOŚCIACH I KONTROWERSJACH W KWESTII TURECKIEJ WYPRAWY NA WIEDEŃ W 1683 ROKU
}

\author{
DARIUSZ WYBRANOWSKI
}

\begin{abstract}
Dariusz Wybranowski, O niektórych mitach, nieścisłościach i kontrowersjach w kwesii tureckiej wyprawy na Wiedeń w 1683 roku (About some myths, inaccuracies and controversies concerning the Turkish expedition to Vienna (1683)).
\end{abstract}

KEYwords: The Battle of Vienna 1683, Polish-Turkish Wars at $17^{\text {th }}$. Century, King John III Sobieski, Kara Mustapha, The Expansion of Ottoman Empire in Europe

Balcanica Posnaniensia. Acta et studia, XXI, Poznań 2014, Wydawnictwo Instytutu Historii UAM, pp. 63-102, ISBN 978-83-63047-59-7, ISSN 0239-4278. Polish text with a summary in English.

Dariusz Wybranowski, Uniwersytet Szczeciński, Instytut Politologii i Europeistyki, ul. Krakowska 71/79, 71-017, Szczecin, dariusz_wybranowski@poczta.fm.

\section{WSTĘP}

Wyprawa wiedeńska Kara Mustafy i odsiecz Wiednia, a także działania wojenne na terenie Dolnej Austrii i Styrii znalazły odbicie w historiografii austriackiej i niemieckojęzycznej, jak również w książkach poświęconych sylwetkom cesarza Leopolda I Habsburga oraz Eugeniusza Sabaudzkiego ${ }^{1}$. Zagadnienia te znalazły swoje miejsce w dosyć licznej polskiej literaturze problemu dotyczącej wyprawy 1683

${ }^{1}$ Por. R. Lorenz, Türkenjahr 1683, das Reich in Kampf um Ostraum, W. Braumüller 1033; W. Sturminger Die Türken vor Wien, Karl Rauch Verlag 1968; Ch. Wessely, Die Türken und was von ihnen blieb, Verband der Wissenschaft Geschichte Österreichs, 1978; R. F. Kreutel, K. Teply, Kara Mustafa vor Wien: 1683 aus der Sicht türkischer Quellen, Steiermark 1982; K. Guthas, Niederősterreich in Türkenjahr 1683, Museumsverein Pottenbrunn 1683; idem: Geschichte Niederősterreich, Verlag für Geschichte und Politik 1984; J. P. Spielman Leopold I. Zur Macht nicht geboren Neue Deutsche Biogaphie, Duncker\&Humblot, Berlin 1985; A. Schindling, Leopold I. (deutscher Kaiser) In: Ders. W. Ziegler, (Hrsg.) Die Kaiser der Neuzeit, München 1990; K.-P. Matschke, Das Kreuz und Halbmond: die Geschichte der Türkenkriege, Artemis\&Winkler 2004; H. Egghardt, Prinz Eugen. Der Philosph in Kriegsrüstung, Verlag Kremayr \&Scherian 2007; E. Eickhoff, R. Eickhoff, Venedig, Wien und die Osmanen: Umbruch in Südosteuropa 1645-1700, Klett-Cotta 2008; H. Lacom, Niederősterreich brennt!, Tatarisch-osmanische Kampfeinheiten 1683, Verlagsbuchhandlung Stőhr 2009; W. Oppenheimer, Prinz Eugen von Savoyen. Feldherr und Baumeister Europas, Amalthea Verlag 2010; Wien-Türkenbelagerung, http://www.wien-vienna.at/tuer kenkriege.htm.; 1683. Die Türken vor Wien, http://www.doppeladler.com/da/kuk/1683-tuerken-vor- 
roku, także tej poświęconej wojnom polsko-tureckim, oraz w biografiach Jana III Sobieskiego ${ }^{2}$. Temat bitwy wiedeńskiej znalazł się też, siłą rzeczy w różnych syntezach dotyczących dziejów Turcji ${ }^{3}$. Ma także odbicie w pracach dotyczących wojskowości polskiej XVII wieku, czy działań prowadzonych w dalszej części kampanii 1683 roku lub w latach następnych przeciw Turkom i Tatarom ${ }^{4}$. Podczas zaborów wątek ten znalazł się także w jednej z mniej znanych książek Henryka Sienkiewicza Na polu chwały, choć autor ten, piszący „,ku pokrzepieniu serc” nie omówił samej bitwy, bo uważał, że właśnie od tego momentu datował się zmierzch i widoczny początek słabości Rzeczypospolitej ${ }^{5}$.

O ile raczej nie podlega dyskusji doniosłość wiktorii wiedeńskiej, tak w dziejach świata, jak i dla samej historii Polski, o tyle bitwa ta, z czasem obrosła w różnorodne mocno utrwalone mity i uproszczenia, tak w tradycji, jak i w powstałej historiografii. Również doczekała się ona nie tylko zadawnionych sporów i sądów na temat celowości, czy w ogóle jakiejkolwiek potrzeby polskiej pomocy dla Habsburgów, któ-

wien/. O roli księcia Eugeniusza w bitwie pod Wiedniem, por. także W. Oppenheimer, Eugeniusz książę Sabaudzki, przekł. A. Marcinek, Warszawa 1997, s. 48-50.

${ }^{2}$ Por. m.in. M. Sadzewicz, Jan III Sobieski 1629-1696, seria: Bitwy, Kampanie, Dowódcy (dalej BKD), 1972/6; Venimus, Vidimus, Deus vicit. Wiktoria wiedeńska 1683 roku w relacjach i dokumentach z epoki. Opr. M. Nagielski, wstęp T. Wasilewski, Warszawa 1984 (dalej jako VVDV); J. Woliński, Z dziejów wojen polsko-tureckich, Warszawa 1983, s. 182 i n.; J. Pajewski, Buńczuk i koncerz. Z dziejów wojen polsko- tureckich, Warszawa 1983, s. 214 i n.; Z. Wójcik, Jan Sobieski 1629- 1696 (wyd. 2), Warszawa 1983, s. 317 i n.; O. Forst de Battaglia, Jan Sobieski król Polski, Warszawa 1983, s. 196 i n.; L. Podhorodecki, Wiedeń 1683 (wyd. 2), Warszawa 2001, seria: Historyczne bitwy, s. 41 i n.; idem: Jan III Sobieski, Warszawa 2010 i w ostatnich latach : J. Stoye, Oblężenie Wiednia, N. Davies, Spuścizna Sobieskiego, Kraków 2009, s. 123 i n.; S. Millar, Odsiecz wiedeńska 1683, Osprey Publishing, wyd. polskie Poznań 2011, s. 61 i n.; W. Konopczyński, Polska a Turcja 1683-1792, Kraków 2013; M. Nagielski, Sobieski - wódz zawołany, „Mówią Wieki”. Magazyn Historyczny, Nr 9/13 (644), s. 24-28; P. Kroll, Venimus, vidimus, Deus vicit! - dzieje wielkiego zwycięstwa, „Mówią Wieki”, op. cit., s. 34-40; I. Kienzler, 1683 Wiedeń, seria: Zwycięskie bitwy Polaków, t. 3, Warszawa 2014.

${ }^{3}$ Por. J. Reychman, Historia Turcji, Wrocław, etc 1973, s. 108; S. Turnbull, The Ottoman Empire 1326-1699, Routledge 2003, s. 89-91; Dzieje gospodarcze i społeczne imperium osmańskiego 1300-1914, red. H. Inalcik, D. Quataert, Kraków 2008, s. 371-372.

${ }^{4}$ Por. m.in. M. Sadzewicz, Pod Wiedniem i Parkanami, BKD 1967/5; P. Brouček, W. Leitsch, K. Vočelka, J. Wimmer, Z. Wójcik, Zwycięstwo pod Wiedniem 1683; J. Wimmer, Odsiecz wiedeńska 1683 roku, Warszawa 1983; idem: Wiedeń 1683. Dzieje kampanii i bitwy, Warszawa 1983, s. 290 i n; idem: Wojsko polskie w drugiej połowie XVII wieku (wyd. 2), Oświęcim 2013, s. 195 i n.; J. Tazbir, Polskie przedmurze chrześcijańskiej Europy. Mity a rzeczywistość historyczna, Warszawa 1987, s. 86 i n.; W. Wasilewski, Wyprawa bukowińska Stanisława Jabłonowskiego w 1685 roku, Warszawa 2002, s. 14 i n.; J. Wojtasik, Podhajce 1698, Warszawa 2008; R. Sikora, Husaria pod Wiedniem 1683, Warszawa 2012, s. 77 i n.; T. Bohun, Parkany. Porażka i zwycięstwo Jana III, „Mówią Wieki”, op. cit., s. 44 i n.; M. Mackiewicz, Wiedeń 1683. Formacje. Barwa i broń, „Mówią Wieki”, op. cit., s. 48-52; M. Wagner, Kampania żwaniecka 1684 roku, Warszawa 2013; Ł. Pabich, Zenta 11 IX 1697, Zabrze-Tarnowskie Góry 2012, s. 8 i n.

${ }^{5}$ Sienkiewicz zakończył swą książkę w momencie wyruszenia i jednoczesnego otrzymania przez Jana III listu od księcia Karola Lotaryńskiego o zwycięstwie pod Preszburgiem i chwale zaciężnych sił polskich. Armia koronna wyruszała wówczas z Tarnowskich Gór w kierunku Śląska, a finałem jest wspaniały pod względem literackim opis poszczególnych formacji, w tym zwłaszcza choragwi husarskich, por. idem: Na polu chwały, Lublin 1986, s. 247 i n. O trasie przemarszu armii i jej części składowych, por. m.in. M. Nagielski, VVDV, op. cit., s. 54-56; O. Forst de Battaglia, op. cit., s. 198-199. 
rzy ponad 80 lat później uczestniczyli w rozbiorach Rzeczypospolitej. Mitologizacji, zwłaszcza ostatnio, uległa też wielkość armii osmańskiej, która jakoby miała liczyć sobie około 300 tysięcy ludzi, poza tym, przedmiotem wielu dyskusji i polemik stały się takie czynniki jak niedostateczny stan przygotowania sił Kara Mustafy do oblężenia Wiednia. Sama zaś decyzja Osmanów o marszu pod habsburską stolicę i chęć jej zdobycia miała być efektem całkowicie jednostkowej decyzji, bezgranicznej pychy i megalomanii wielkiego wezyra, który na dodatek okazał się kompletnie nieudolnym wodzem i architektem klęski. Niektóre z analizowanych w niniejszej publikacji sądy zostały mocno utrwalone w powszechnej świadomości, nadal są też obecne w programach szkolnych, czy w mediach. Powodem, dla którego ostatnio na nowo podjęto na dużą skalę polemikę na ten temat był film w reżyserii Renzo Martinellego, ,Bitwa pod Wiedniem" (2012) prezentowany kilka lat temu z okazji jej kolejnej rocznicy ${ }^{6}$. Jedno jest pewne - ewentualne zwycięstwo tureckie i zdobycie Wiednia miałoby ogromny wpływ na dalszą historię Europy, podobnie jak klęska osmańska stała się początkiem zmian w ówczesnym układzie sił. Obecny artykuł jest zatem próbą podjęcia na nowo analizy, czy oceny niektórych zagadnień związanych z wyprawą wiedeńską w świetle źródeł i literatury problemu i otwiera drogę do kolejnych dyskusji i polemik.

\section{KONTROWERSJE NA TEMAT CELÓW WYPRAWY KARA MUSTAFY W 1683 ROKU I KIERUNKU GŁÓWNEGO UDERZENIA. MIT I LEGENDA O ZAMIARZE MARSZU NA ITALIĘ I ZDOBYCIA RZYMU}

Dość powszechnym poglądem utrwalonym w świadomości potocznej, jest od dawna realizacja niesłychanie ambitnego zamiaru wielkiego wezyra bezpośredniego marszu na Wiedeń i zdobycia habsburskiej stolicy. Kara Mustafa nie był pierwszym z Osmanów, który zamierzał zająć to miasto. Próbował tego jeszcze w 1529 roku sułtan Sulejman II Wspaniały, jednak wówczas potężnej armii sułtańskiej nie udało się tego dokonać, m.in. z uwagi na perspektywę nadejścia zimy ${ }^{7}$. Czy zatem panują-

\footnotetext{
${ }^{6}$ Por. Bitwa pod Wiedniem (11 settembre 1683), http://vod.pl/filmybitwa-pod-wiedniem/45f6s; Bitwa pod Wiedniem- zwiastun teaserowy- w kinach od 12 października 2012!, http://www.youtube.com /watch? $=\mathrm{jD} 4 \mathrm{rXCqed7Y.}$

7 Por. J. Reychman, op. cit., s. 68; H. Wereszycki, Historia Austrii, Wrocław etc. 1986, s. 73. Wyprawa osmańska z 1529 roku miała znacznie większy zasięg terytorialny, aniżeli ta z 1683. Główne siły dowodzone przez samego sułtana rozbiły pod miasteczkiem Bruck nad Litawą (Bruck a.d. Leitha) część armii habsburskiej, próbującej odeprzeć najazd turecki, biorąc m.in. do niewoli 6 generałów. Druga część wojsk inwazyjnych, dowodzona przez Yahyę Gazi Mehmeda beja zajęła m.in. Brno na Morawach, bawarski Regensburg i Maribor (dziś w Słowenii). Silny oddział osmański dowodzony przez beja Kasima Małkocz-ogłu (tur. Kasim Malkoç-oglu) opanował miasto Vaduz i wziął w jasyr syna księcia Liechtensteinu. Istotnym sukcesem Osmanów było także zajęcie Grazu - drugiego co do znaczenia miasta austriackiego. 27 września 1529 roku armia sułtana stanęła pod Wiedniem. Jednak po 19 dniach Sulejman II przerwał oblężenie, najprawdopodobniej z uwagi na perspektywę długotrwałych działań oblężniczych i obawę przed szybkim nadejściem zimy. Co ciekawe, sułtan pozostawił ciężką artylerię w Budzie, zatem
} 
cy współcześnie z wielkim wezyrem, sułtan Mehmed IV (1648-1687), zazdroszczący sławy swemu wielkiemu poprzednikowi nakazał Kara Mustafie marsz na Wiedeń, czy też za tę decyzję, podjętą bez porozumienia z sułtanem, był odpowiedzialny sam wielki wezyr i czy rzeczywiście to miasto od początku było głównym celem wielkiej wyprawy osmańskiej? Czy Wiedeń nie był tylko jednym z etapów nowej fazy podboju Zachodu i chęci zdobycia przez Turków nie tylko Austrii, ale i Italii, a zwłaszcza symbolu chrześcijaństwa zachodniego - Rzymu?

Podobnie jak i w innych aspektach rekonstrukcji wyprawy wiedeńskiej armii osmańskiej Kara Mustafy, odpowiedź znajduje się w analizie ówczesnych przekazów kronikarzy tureckich, a zwłaszcza Silahdara Mehmeda agi z Fyndykły, Dżebedżiego Hasana Esiriego, Huseina Hezarfenna, defterdara Sary Mehmeda paszy, zachowanej korespondencji wielkiego wezyra, czy Kroniki Mehmeda Gireja ${ }^{8}$.

W dniu 21 stycznia w Adrianopolu (tur. Edirne) wystawiono buńczuki sułtańskie jako symbol rozpoczęcia wojny, a pod miastem rozpoczęto stopniowe gromadzenie armii, w tym formacji janczarów, azabów i innych jednostek piechoty, a także sił złożonych z jazdy, zwłaszcza sipahiów, silahdarów i delich. W drugiej połowie marca 1683 roku Mehmed IV przeniósł się do obozu swych wojsk, ponadto nadciągnęły korpusy wojsk technicznych, topczych, dżebedżich i innych ze sprzętem inżynieryjnym i artylerią. Koncentracja sił osmańskich, (a zwłaszcza niemal 10 tysięcy janczarów) i jej marsz przez m.in. Swilengrad, Płowdiw, Pazardżik, Sofię, Sliwnicę, Niš, Aleksinac do Belgradu jest znana z relacji posła habsburskiego Caprary, który wraz z innymi dyplomatami spisywał swe wrażenia, znane potem z opublikowanej relacji'.

Na przestrzeni kwietnia - początku czerwca główne siły dotarły do Osijeku nad Sawą, a stamtąd ruszyły dalej w kierunku granicy z państwem Habsburgów ${ }^{10}$. Bardzo dużo informacji na temat pierwotnego planu kampanii przeciw Austrii zawiera wspomniana relacja Silahdara Mehmeda agi. Rzeczony dziejopis sporządził dokładny opis narady wojennej, odbytej w dniach 25-26 czerwca 1683 roku, pod Stołecznym Białogrodem (węg. Székesfehérvar), z udziałem samego wielkiego wezyra, licznych bejlerbejów/ paszów i agów (przybyłych z siłami swych elajetów), a szczególnymi gośćmi byli chan Murad Girej z synami, nureddin i grupa możnych i urzędników tatarskich ${ }^{11}$.

podobnie jak Kara Mustafa nie spodziewał się istotnego i długiego oporu. Por. J. S. Lątka, Sulejman II Wspaniały, Warszawa 2004, s. 54-56.

${ }^{8}$ Wspomniane relacje znalazły się w wydanym zbiorze i przetłumaczonym na polski: Kara Mustafa pod Wiedniem. Źródła muzułmańskie do dziejów wyprawy wiedeńskiej 1683 roku, przekład z tureckiego i opracowanie Z. Abrahamowicz, Kraków 1973.

${ }^{9}$ O szczegółowej trasie marszu Osmanów, por. J. Wimmer, Wiedeń 1683, op. cit., s. 168-169.

${ }^{10}$ Ibidem, s. 169-172.

${ }^{11}$ Wśród obecnych gości tureckich Kara Mustafy byli wymienieni zwłaszcza: Kủczúk Hasan pasza (beglerbej Rumelii), Ahmed pasza (beglerbej Anatolii), Kodża Arnawud Ibrahim pasza (beglerbej Budy), Abaza Sary Hasan pasza ( beglerbej Damaszku), Kara Mehmed pasza (beglerbej Silistrii), Mustafa pasza (namiestnik Mityleny), Czelebi Ismail aga (kiahia bej kułów), Bekri Mustafa pasza (janczar aga), czawusz pasza (çavus paşa), ponadto bőlük agowie, dżebedżi paszowie, topczy paszowie i inni wojskowi osmańscy, licznie przybyli do namiotu wezyrskiego. Oprócz nich obecni byli Tatarzy, tj. przedstawi- 
Baza źródłowa dość dokładnie prezentuje osoby osmańskich dowódców i niekiedy stara się podać dokładną liczbę ich wojsk, które uczestniczyły w wyprawie wiedeńskiej, choć nie zawsze prawdziwą ${ }^{12}$. Podczas trwania narady, Kara Mustafa tak prowadził jej przebieg, by skłonić zebranych, czy raczej narzucić wszystkim obecnym swój zamiar marszu na Wiedeń. Nie obyło się bez zwyczajowego odśpiewania pieśni zwycięstwa „Fatihy”, a także tradycyjnych podarunków, tj. ozdobnych kaftanów (tur. chylat), a sam chan otrzymał kurtę ze złotogłowiu, ozdobny kaftan i szablę wysadzaną klejnotami ${ }^{13}$.

Z przekazu Silahdara Mehmeda agi wyraźnie wynika, że celem zebranej armii osmańskiej pierwotnie były zamki [i miasta] Jawaryn (obecnie Győr) i Komarno (węg. Komárom $)^{14}$. Wielki wezyr jednak uważał, że zdobycie owych zamków oznacza jedynie lokalne sukcesy, a nie zdobycie całego kraju, tj. Węgier, ale i najprawdopodobniej docelowo także i reszty państwa Habsburgów, a zwłaszcza samej Austrii ${ }^{15}$. Chyba tylko dla formalnego porządku i z wymuszonej sytuacją kurtuazji, wielki wezyr zapytał Abazę Sary Hasana paszę o jego zdanie w tej mierze. Beglerbej damasceński uchylił się jednak od odpowiedzi wprost, mówiąc o koniecznym posłuszeństwie wobec rozkazów i służbie. Inni dostojnicy osmańscy także woleli się nie narażać Kara Mustafie, swymi wątpliwościami, czy sprzeciwem, tym bardziej, że widzieli, iż właściwie decyzja została już przez niego samego całkowicie już podjęta. Jedynymi obecnymi, którzy ośmielili się mieć odrębne zdanie byli chan tatarski i Ibrahim pasza z Budy. Murad Girej wskazał na bardzo trudne warunki marszu sił tatarskich i osmańskich przez obszar Karyntii, który nie przyniesie spodziewanych korzyści, a tylko straty w wojsku i w zwierzętach, ani też nie da „upragnionej zemsty na Niemcach"16. Znacznie bardziej przekonywujące argumenty miał Ibrahim pasza, który wskazał na korzyści ze zdobycia Jawaryna i Komarna i stworzenia z nich baz wypadowych dla zagończyków - akyndżych (tur. akinçi) i Tatarów, którzy zrujnują ziemie przeciwni-

ciele dynastii Girejów i ich urzędnicy dworscy. Por. Silahdar Mehmed aga z Fyndykły (dalej jako SMaF), op. cit., s. 95-96. Osoby znanych źródłowo dowódców tureckich i siły ich kontyngentów z 21 elajetów Imperium Osmańskiego podaje L. Podhorodecki, por. idem: Wiedeń 1683, s. 43-44.

12 Jednym z pierwszych polskich zapisów źródłowych z 1683 roku o liczebności armii osmańskiej w wyprawie wiedeńskiej i kampanii węgierskiej była kronika prowadzona przez księdza Benedykta Samotulskiego, przeora kanoników regularnych klasztoru św. Piotra i Pawła na wileńskim Antokolu i zarazem proboszcza tamtejszej parafii. Przy poszczególnych paszach podawał on także liczbę wojsk, które mieli ze sobą przywieść (np. Kara Machmet Bassa Mesopotamiae - 5000, Hassan Bassa Damasci - 3000). Ogółem armia sułtańska miała liczyć wraz z Tatarami i sprzymierzonymi Wegrami aż ponad 200 tysięcy wojska. Por. A. S. Czyż, Bitwa pod Wiedniem w relacji proboszcza antokolskiego Benedykta Samotulskiego, ,Studia Wilanowskie” 2010, t. 17, s. 25-29, http://www.wilanow-palac-download.php/ 23029/sw_17art3.pdf. Na temat badań nad liczebnością armii Kara Mustafy w dalszej części artykułu.

${ }^{13}$ Por. SMaF, op. cit., s. 96.

${ }^{14}$ Ibidem. Na temat planów wojennych Osmanów z lat 1682-1983 i celów nowej kampanii, por. także m.in. J. Wimmer, Wiedeń, op. cit., s. 149-150 i 170; L. Podhorodecki, op. cit., s. 39 i n.; S. Turnbull, op. cit., s. 89; J. Stoye, op. cit., s. 40 i n.; P. Kroll, op. cit., s. 35.

${ }^{15}$ Por. SMaF, op. cit., s. 97.

${ }^{16}$ Ibidem, s. 97-98. 
ka, tak by ułatwić przyszły podbój, a w następnym roku dokonać właściwej wyprawy na Wiedeń ${ }^{17}$.

Ibrahim pasza szczególnie przestrzegał Kara Mustafę, że wyprawa na stolicę habsburską może doprowadzić do zaniechania istniejących sporów u chrześcijan (giaurów) i ruszenia przez nich na pomoc cesarzowi, ten ostatni argument podał też nieco wcześniej chan ${ }^{18}$. Głównym kontrargumentem wielkiego wezyra było jednak to, że zdobycie Wiednia, niejako samoczynnie odda bardzo liczne zamki i miasta habsburskich Węgier, w tym Jawaryn i Komarno w ręce Osmanów. Zatem, jego zdaniem, państwo osmańskie nie będzie miało z obu zamków żadnej korzyści, ponieważ staną się jedynie timarami i ziametami w rękach lenników wojskowych, tj. będzie to sukces bardzo niewielki, natomiast zdobycie Wiednia (i jak największej części Austrii) spowoduje, że problem węgierski wobec tak dotkliwej klęski Habsburgów zostanie rozwiązany jako swego rodzaju naturalna konsekwencja polityczno-militarna. Poza tym, pieniqdze, kule i amunicja, jakie musielibyśmy stracić pod tymi zamkami, przydadza się nam pod Wiedniem ${ }^{19}$.

Wielki wezyr był tak już zaślepiony swym pomysłem, że wątpliwości chana i zwłaszcza Ibrahima paszy, którego od dawna nie lubił, wywołały jego ogromny gniew $^{20}$. Silahdar Mehmed aga podał, że

Następnie wielki serdar ogłosił, że każdego, kto go będzie od tej drogi odwodził, bezlitośnie straci. W ten sposób otumanił ludzi, więc wszyscy zdali się na Boga i tylko na cuda Boże czekali²1.

Kara Mustafa nie zapomniał swym adwersarzom ich sprzeciwu i wątpliwości - chan nie był więcej, mimo swej wysokiej pozycji i urodzenia, więcej zapraszany na kolejne narady, zaś Ibrahim pasza, już po klęsce wiedeńskiej został oskarżony o sprowokowanie owego nieszczęścia i pod obleganym przez siebie Jawarynem stracony ${ }^{22}$. Z kolei chan Murad Girej został potem przez Kara Mustafę złożony z tronu. Zapewne też, wzorem innych wodzów, mających ogromną armię i widząc słabość liczebną przeciwnika, wierzył głęboko, że odniesie wielkie zwycięstwo. Utwierdziła go w tym także porażka sił habsburskich pod Petronell (7 lipca), która miała fatalny wpływ psychologiczny na morale Austriaków. Nie pomogła także w jego podtrzymaniu ewakuacja Leopolda I wraz z całym dworem do Linzu ${ }^{23}$. Poza tym, wielki wezyr był pewien, że brak perspektywy odsieczy, czy dostatecznej pomocy dla cesarza i jego stolicy oraz potęga jego wojsk będą tymi czynnikami, które przesądzą o beznadziejności stawiania dalszego oporu.

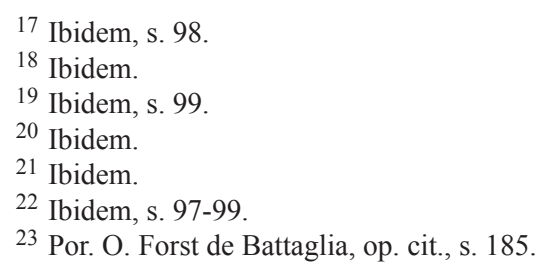


Jednak, jak wskazał m.in. John Stoye, Wiedeń był wówczas dzięki swym potężnym fortyfikacjom, zbudowanym i rozbudowywanym od XVI wieku przez inżynierów włoskich, dość dobrze przygotowany nawet na długotrwałe oblężenie ${ }^{24}$. To kompensowało w znacznym stopniu liczebną dysproporcję sił, jednak Kara Mustafa zupełnie nie brał tego pod uwagę. Rzeczywiście, już znacznie gorzej było z liczebnością załogi miasta (około 12 tysięcy ludzi) i zaopatrzeniem w środki walki, a zwłaszcza dostateczne zapasy prochu i kul, także i żywności, w razie gdyby oblężenie zaczęło się przedłużać 25 .

Dodatkowym elementem, który zapewne umocnił determinację $\mathrm{i}$ wiarę w powodzenie wyprawy u wielkiego wezyra było przybycie kolejnych wojsk prowadzonych przez sześciu sandżakbejów anatolijskich (m.in. Ali bej z Amasyi, Ahmet bej z Malatyi, Sulejman bej z Alaiye), wymienionych kolejno przez kronikarza ${ }^{26}$. Oprócz nich, podczas wyprawy obecni byli Chyzyr pasza (beglerbej Bośni) i Szejch-ogłu Ali pasza (beglerbej Egeru) z siłami swych elajetów ${ }^{27}$.

$\mathrm{Z}$ różnorodnych przekazów i informacji związanych z wyprawą Kara Mustafy dość dobrze można odtworzyć udział poszczególnych dowódców osmańskich, z obowiązku lennego stawić musieli się także chrześcijanie - hospodarowie Wołoszczyzny Şerban Cantacuzino i Mołdawii - Jerzy Duca oraz książę Siedmiogrodu - Michał Apáffi. Zgromadzone siły osmańskie imponowały swą liczebnością, barwnością, uzbrojeniem i różnorodnością. Kronikarz Silahdar Mehmed aga z Fyndykły wkłada w usta wielkiego wezyra, podczas dotarcia sił osmańskich pod Jawaryn (1 lipca) jego zachwyt nad

mnóstwem, liczebnością i wspaniałością wojsk muzułmańskich, o której nigdy nie słyszano, ani nigdy czegoś podobnego nie oglądano ${ }^{28}$.

Inny ze współczesnych dziejopisów, Dżebedżi Hasan Esiri także będący świadkiem tego wydarzenia, pisał:

Owo przestronne pole [pod Jawarynem - DW] było wówczas tak zatłoczone wojskiem, że zdawało się, że zebrali się na nim co do jednego wszyscy ludzie oraz wszystkie konie, wielbłądy, woły i owce jakie są tylko na świecie ${ }^{29}$.

Współcześnie, niektórzy XVII-wieczni autorzy, jak poeta z Dubrownika, Petar Kanavelović w jednym ze swych poematów pisał, że wielki wezyr po zdobyciu Wiednia i ziem Austrii będzie chciał zdobyć Rzym, a potem w dowód zwycięstwa

24 Obszernie na temat systemu fortyfikacji i umocnień Wiednia oraz wykorzystaniu jego warunków naturalnych, por. J. Stoye, op. cit., s. 63-67.

25 Por. S. Millar, op. cit., s. 43.

26 Por. SMaF, op. cit., s. 99.

27 Ibidem.

28 SMaF, op. cit., s. 100-101.

29 Por. Dżebedżi Hasan Esiri (dalej DHE), [w:] Kara Mustafa, op. cit., s. 217. 
i upokorzenia Papiestwa i całego chrześcijaństwa, urzadzić w bazylice św. Piotra stajnie dla koni sultańskich ${ }^{30}$.

Była to także część planu tureckiego polegającego na zdobyciu na pół legendarnego tzw. „Czerwonego Jabłka” (tur. Kizil Elma), tj. właśnie Rzymu, którego symbolem miała podobno być kopuła bazyliki św. Piotra ${ }^{31}$. W lecie 1683 roku, w związku z realną perspektywą upadku Wiednia zaczęto obawiać się dalszego marszu armii wielkiego wezyra nawet na Rzym, co miało stanowić dla Europy śmiertelny cios. Bał się tego nawet sam papież Innocenty XI, który zwrócił się z prośbami o pomoc do obu dożów Wenecji, władz Republiki Genui, wielkiego księcia Toskanii, księcia Sabaudii, Modeny, Parmy i kilku innych państw italskich ${ }^{32}$. Jak wskazał Otto Forst de Battaglia pojawiła się nawet zapowiedź wielkiego wezyra o tym, że po stolicy cesarskiej przyjdzie kolej na Rzym ${ }^{33}$. Kara Mustafa mógł mieć podobny zamysł, lub też tego rodzaju zapowiedzi miały na celu doprowadzenie do upadku ducha, złamania woli oporu, czy zastraszenie, co jest zawsze typowym zresztą celem propagandy wojennej.

Tego rodzaju groźne i buńczuczne wypowiedzi miały jednak wówczas niewielkie realne znaczenie, choć wielu Europejczyków na pewno mogły wtedy naprawdę przerazić. $Z$ uwagi na aspekt przestrzenny, logistyczny, długość drogi, zwłaszcza przez Alpy Julijskie, liczne tamtejsze zamki i inne fortyfikacje przede wszystkim, nowy wielki marsz ,zaraz po zdobyciu Wiednia”, był jednak mało możliwy. Wymagał bowiem konsolidacji nowych zdobyczy, przybycia kolejnych nowych oddziałów, dokonania ogromnych uzupełnień i koniecznego przeorganizowania armii, na co absolutnie niezbędny był dłuższy czas. Wielkiego wezyra czekałby też prawdopodobnie przemarsz przez terytorium Republiki Weneckiej, a Wenecjanie zrobiliby wszystko, by armię osmańską zatrzymać i na pewno podjęli by walkę z nią. Jest też oczywiste, że podobna wyprawa wymagałaby znacznie większej ilości wojsk (nie mówiąc

30 Por. J. Śliziński, Jan III Sobieski w literaturze narodów Europy, Warszawa 1979, s. 198; L. Podhorodecki, Wiedeń 1683, s. 16-17. Być może podobne opinie były wyrazem panującej od dawna obawy mieszkańców znacznej części Europy przed grozą najazdów tureckich i ekspansją osmańską. O podobnych nastrojach istniejących zwłaszcza od XVI wieku, por. J. Tazbir, Polskie przedmurze, op. cit., s. 46-50 , a ponadto znany historyk francuski, Jean Delumeau, por. tegoż, Strach w kulturze Zachodu, Warszawa 1986, s. 247-256.

$31 \mathrm{~W}$ przypisach do wspomnianego wyżej zbioru kronik dotyczącego wyprawy Kara Mustafy na Wiedeń, Zygmunt Abrahamowicz pisze, że: „Czerwone Jabłko” oznaczało w dawnej Turcji opisową nazwę wielkiego i bogatego miasta w Europie Zachodniej. Jego zdaniem, przypuszczalnie chodziło o Rzym z jego widoczna, świecącą z daleka miedzianą kopułą bazyliki św. Piotra. Nazwa ta odnosiła się także najprawdopodobniej i do Wiednia lub węgierskiego Ostrzyhomia, którego katedra górowała nad okolica. Źródłem tego podania mogą być, zdaniem Z. Abrahamowicza także legenda bizantyjska o „Złotym Jabłku", bądź na poły fantastyczny opis Wiednia, dokonany przez podróżnika osmańskiego i kronikarza, Evliyi Czelebiego (tur. Çelebi) . Por. Kara Mustafa pod Wiedniem, op. cit., s. 361-362, przyp. 248. Można jedynie dodać, że zamiar zdobycia Rzymu stanowił w polityce osmańskiej element stały, swoisty symbol i długofalowy cel. Był to jednak cel typowo ideologiczny, natomiast z uwagi na ówczesne możliwości militarne Imperium, mało realny, bez wielkiej operacji morsko-lądowej, także od strony Morza Tyrreńskiego.

32 Por. O. Forst de Battaglia, op. cit., s. 204.

33 Ibidem. 
o ich zaopatrzeniu), bo przecież, z uwagi na ogromne wydłużenie drogi trzeba byłoby obsadzić zajęte twierdze i miasta niekiedy przynajmniej 300-400 żołnierzami. Co najwyżej, Italia północna zostałaby spustoszona przez lotne oddziały tureckie i tatarskie, jednak raczej mało prawdopodobne, by trwale zajęta. Poza tym, prawdopodobny opór nadwątliłby po drodze siły Osmanów, a reszty dokonałyby coraz większe trudności w aprowizacji bardzo licznej przecież armii inwazyjnej. Być może, kwestia ta nie wymagałaby więcej uwagi, gdyby nie kolejny czynnik kreacji mitu na ten temat. Wątek ten, jako kolejny element „wojny cywilizacji” pojawił w się w książce Cezarego Harasimowicza i jego powieści o zwycięstwie wiedeńskim, o której w innym miejscu, a poza tym także i w we wspomnianym filmie R. Martinellego, obejrzanym przecież w bardzo dużej liczbie krajów na świecie.

\section{PROBLEM LICZEBNOŚCI WOJSK KARA MUSTAFY W 1683 ROKU ORAZ JEGO NIEPRAWDZIWA KREACJA I MITOLOGIZACJA W MEDIACH I W LITERATURZE}

Praktycznie od samego początku, tj. od 1683 roku zawyżano ilość sił Kara Mustafy. Cytowany już kronikarz, ks. Benedykt Samotulski z wileńskiego Antokolu pisał o ponad 200 tysiącach ludzi. Pułap „,kilkuset tysięcy” Turków przeciw „,znacznie słabszej”, czy ,znacznie mniejszej” armii koalicji chrześcijańskiej, czy wcześniej tylko samej armii habsburskiej brzmiał bardzo dobrze także i po to, by to wielkie zwycięstwo było jeszcze bardziej efektowne i chwalebne. Późniejsze badania historyków polskich i obcych zmniejszyły ten bardzo wysoki pułap przewagi do bardziej realnych rozmiarów. Na samym początku kampanii, w momencie wymarszu wojsk Kara Mustafy, łącznie z kontyngentami chrześcijańskich lenników, armia sułtańska m.in. według szacunków Jana Wimmera miała liczyć aż 150-160 tysięcy. Podczas decydującego starcia, 11-12 września wielki wezyr mógł wystawić przeciwko siłom koalicji efektywnie od 63 do 65 tysięcy, oprócz tego część wojsk, tj. nieco ponad 20 tysięcy nadal szturmowała mury Wiednia i prowadziła działania oblężnicze ${ }^{34}$. Zbliżony pułap co do wysokości sił tureckich w momencie rozpoczęcia kampanii, tj. około 165 tysięcy podaje Otto Forst de Battaglia, według niego wielki wezyr posiadał 10 września już tylko około 140 tysięcy wojska ${ }^{35}$. Jednak już Leszek Podhorodecki szacuje armię Kara Mustafy na znacznie mniej, bo na 110 tysięcy, jednak jej liczebność (na skutek różnych strat i rozproszenia sił w trakcie kampanii) w momencie początku bitwy miała wynieść faktycznie już tylko 55-60 tysięcy, a w obozie miało ponadto przeby-

34 Por. J. Wimmer, Wiedeń 1683, op. cit., s. 174. Oprócz tego, w zdobytym namiocie wezyrskim znaleziony został spis armii, który podawał liczbę 170 tysięcy żołnierzy sułtańskich. Te dane traktowane są jednak jako ,podawane na wyrost”, m.in. w celu uzyskania dodatkowych przydziałów żywności i paszy (por. J. Wimmer, op. cit. s. 306). Pułap w wysokości 150-160 tysięcy za J. Wimmerem podają też inni autorzy, por. m.in. A. S. Czyż, op. cit., s. 28; P. Kroll, op. cit., s. 35.

35 Por. O. Forst de Battaglia, op. cit., s. 215. 
wać 10 tysięcy rannych i kalek ${ }^{36}$. Zbigniew Wójcik, opisując tylko samą bitwę wiedeńską, podaje, że przeciw armii koalicji walczyło łącznie około 90 tysięcy Turków i około 10 tysięcy Tatarów ${ }^{37}$. Na 90-100 tysięcy szacuje też ogólną liczbę Turków pod Wiedniem Mirosław Nagielski ${ }^{38}$. Obok L. Podhorodeckiego, chyba najdalej w obniżaniu wysokości sił osmańskich pod Wiedniem poszedł Simon Millar, bo według niego wojska tureckie mogły liczyć „,od 28 do 60 tysięcy jazdy” (a ile piechoty i żołnierzy innych formacji?! - DW) ${ }^{39}$. Natomiast siły chrześcijan miały liczyć około $65-$ -70 tysięcy ludzi ${ }^{40}$. Zatem, siły obu stron były 11-12 września nie tylko dość wyrównane, ale według niektórych szacunków i obliczeń, wojska tureckie czynnie mogły liczyć nawet nieco mniej, bo 55-60 tysięcy. Tyle bowiem zostało z pierwotnej liczby 110-140/60 tysięcy z początku kampanii osmańskiej rozpoczętej na Węgrzech.

Obecnie utrwaleniu mitu, czy zupełnej nieprawdy o ,300 tysiącach Turków” pod Wiedniem bardzo sprzyja przede wszystkim wielokrotnie cytowany film R. Martinellego, którego opis i powtarzające się reklamy najczęściej zawiera tę liczbę, która poznały i zapamiętały już miliony odbiorców na świecie ${ }^{41}$. Jest też ona bardzo chwytliwa, dość okrąła i znajduje odbicie niekiedy w różnorodnej amatorskiej twórczości poetyckiej publikowanej w Polsce, również na łamach prasy katolickiej, czy narodowej, np. „Naszego Dziennika”42. Wydaje się, że trudniej będzie przebić się bardziej realistycznym danym o wysokości sił wojsk tureckich w wysokości około 100 tysięcy (w polu około 60-70 tysięcy przeciwko siłom uczestniczącym w odsieczy). Powodem tego jest choćby fakt, że obraz filmowy ma znacznie większy zasięg medialny i informacyjny, niż rozprawy i artykuły naukowe, które mają obecnie znacznie mniej czytelników, niż kino, telewizja i Internet widzów i użytkowników.

36 Por. L. Podhorodecki, Wiedeń, op. cit., s. 110, 121-122.

37 Por. Z. Wójcik, op. cit., s.

38 Por. Czy warto było iść pod Wiedeń? Rozmowa z prof. Mirosławem Nagielskim i dr Dariuszem Milewskim, „Mówią Wieki”, wrzesień 2013, nr 9/13 (644), s. 6-9;

39 Por. S. Millar, op. cit., s. 67.

$40 \mathrm{Na}$ początku 1683 roku armia habsburska liczyła sobie około 60 tysięcy piechoty i kawalerii. Oprócz wojsk polskich Jana III ( $\mathrm{t}$ j. nieco ponad 20 tysięcy) z odsieczą przybyły wojska elektora saskiego Jana Jerzego III, bawarskiego Maksymiliana II Emanuela, kontyngent bawarsko-frankoński margrabiego Ludwika badeńskiego i Jerzego Fryderyka, księcia Waldeck. Łącznie dawało to wspomniane 60-70 tysięcy wojska. Na ten temat por. L. Podhorodecki, op. cit., s. 106; S. Millar, op. cit., s. 61, 95; P. Kroll, op. cit., s. 35.

41 Por. Bitwa pod Wiedniem (11 settembre 1683), http://vod.pl/filmy/bitwa-pod-wiedniem/45f6s.

42 Przykładem fragment wiersza z „Naszego Dziennika”: „, Te kościoły jutro będa meczetami”/ Wołat Kara Mustafa pod Wiednia murami./ Trzysta tysięcy gardeł ryknęło pod niebo:/ „Allah akbar! Mahomet jest prorokiem jego!’/ I każdy z nich byt gotów umrzeć za swa wiarę/I czuło się moc wielka nad tych wojsk bezmiarem... Cyt. za L. Makowiecki, Allah Akbar! „Nie łudźmy się, że prawo szarijatu zatrzyma się nagle na Odrze i Nysie”, http://www.wpolityce.pl/artykuly/54550-allah-akbar-nie ludzmy-sie-ze-prawo-sza riajtu-zat... 


\section{KONTROWERSJE WOBEC NIEWŁAŚCIWEGO PRZYGOTOWANIA ARMII OSMAŃSKIEJ DO ZDOBYWANIA WIEDNIA POD WZGLĘDEM JEJ WYPOSAŻENIA I PRZYCZYN KLECKI}

Oprócz z góry niejako „złej decyzji” Kara Mustafy o rozszerzeniu zasięgu marszu osmańskiego na Austrię i sam Wiedeń, do których to działań jego armia była „zupełnie nie przygotowana" pod względem ilości wojsk, kilka argumentów jest szczególnie podnoszonych. Jednym z kluczowych jest m.in. opinia historyka tureckiego, Feroza Ahmada, którą zaprezentował w wywiadzie dla tygodnika „Newsweek Polska”. Na pytanie „Dlaczego armia ottomańska przegrała?”, wspomniany badacz odpowiedział:

Z dwóch powodów. Po pierwsze, przygotowując najazd na Wiedeń, Kara Mustafa był przekonany, ze od strony Lasu Wiedeńskiego miasto nie będzie chronione. Nie spodziewał się ataku wojsk Sobieskiego, które zdołały przejść przez góry i lasy. Dlatego Sobieski miał przewagę. Po drugie, Mustafa przegrał, bo zabrał ze sobą lekką broń zamiast ciężkiej, która mógłby forsować mury obronne Wiednia. Częściowo było to podyktowane tym, że w oblężeniu z 1529 roku ciężka broń armii utknęła w błocie, bo lato było wtedy w Europie bardzo deszczowe ${ }^{43}$.

Czy rzeczywiście osmański wódz mógł wykazać się takim brakiem wyobraźni, że na oblężenie zamków i miast Węgier, Austrii i samego Wiednia, podczas całej kampanii, w ogóle nie zabrał ze sobą ciężkich dział, najbardziej przydatnych do działań oblężniczych i mogących skruszyć mury nieprzyjacielskich fortec?

Jest to problem dosyć złożony. Pozornie, prostą odpowiedź daje kolejny zapis Silahdara Mehmeda agi o ,zupełnym braku ciężkich dział”:

Dziwne jest jednak, że pomimo takiego przepychu i świetności, pomimo znakomitego uzbrojenia wojsk, pomimo takiego zapasu kul, prochu i sprzętu oraz takich kosztów i wydatków, wielki serdar nie sprowadził wielkich dział i moździerzy [do miotania bomb]. Właśnie rozpoczynając wyprawę na Niemcy i ważąc się w swym sercu na oblężenie zamku takiego jak wiedeński, winien był on wyposażyć obóz wojsk monarszych w czterdzieści, czy pięćdziesiąt bałjemezów z rodzaju tych, które strzelają kulami o wadze co najmniej od dziesięciu do trzydziestu okk, w piętnaście-dwadzieścia armat-kolubryn, w takąż samą liczbę moździerzy do [miotania] bomb oraz ze trzysta szahi-darbuzenów ${ }^{44}$.

Dalej jednak kronikarz trochę sam sobie przeczy, bo wytykając te „rażące błędy” wielkiego wezyra, pisze zarazem o trudnościach logistycznych i transportowych przy tak dużej ilości jednostek artylerii, zwłaszcza tej ciężkiej i zgromadzeniu odpowiedniej liczby zwierząt pociaggowych:

Co prawda, do przewozu takiej liczby dział potrzeba kilku tysięcy par wołów, żeby mieć tyle wołów, musiałoby się spędzić bydło z całej Rumelii. Mógłby tedy ktoś zauważyć, że to pociągnęłoby za sobą

43 Por. Turecki historyk o bitwie pod Wiedniem, http://historia.newsweek.pl/turecki-historyk-o-bi twie-pod-wiedniem,95958,1,1.html.

44 SMaF, op. cit., s. 118. 
konieczność użycia przemocy. Odpowiedź na to jest jednak taka, że były to czasy, kiedy moc i potęga państwa, bogactwo i zasobność skarbu i arsenału była w stanie zagwarantować bezpieczeństwo mienia i inwentarza, zarówno żołnierza muzułmańskiego, jak też rajów [tj. chrześcijańskiej ludności, zwanej przez Osmanów raya - DW] ${ }^{45}$.

Te trudności można było jednakże pokonać według Silahdara Mehmeda agi w sposób następujący:

Gdyby się bowiem, wedle ówczesnych warunków z każdej brody oddało tylko po jednym włosku, to zgromadzenie pięciu, czy dziesięciu tysięcy wołów nie przedstawiałoby trudności najmniejszej, a szczególnie nie dokonałoby się tego przemoca, lecz w drodze kupna ich przez skarb [sułtański DW] za zgodą właścicieli. Wielkich armat nie potrzeba było sprowadzać aż ze Stambułu, bo od dawna istniało prawo pozwalające zabierać je i ściagać z Budzina (tj. Budy) i okolicznych zamków pogranicznych. Dawnymi bowiem czasy padyszachowie i serdarowie z [ich] ramienia, wymuszając na wyprawy węgierskie, zwykli byli brać i sprowadzać wielkie działa wedle potrzeby, najczęściej z zamków pogranicznych"46.

Czy Kara Mustafa zdołałby dostatecznie szybko zebrać dostateczną ilość wołów pociagowych do wspomnianych kilkudziesięciu bałjemezów i aż kilkuset lżejszych armat, tak by działa miały odpowiednią trakcję i mogły znaleźć się jeszcze przed letnimi, czy w najgorszym razie, jesiennymi deszczami pod Wiedniem?! Dodać należy, że tak duża liczba wołów potrzebuje także ogromnych ilości paszy, a poza tym, tak wiele działonów i zwierząt może poruszać się dość wolno, wyraźnie zmniejszając tempo marszu i jako taka staje się ogromnym obciążeniem.

Być może istniały powody, dla których armia wielkiego wezyra nie przyprowadziła ze sobą [aż tylu] wielkich dział oblężniczych, które na pewno znacznie szybciej skruszyłyby wiedeńskie mury i bastiony i zmusiły załogę do kapitulacji. Zapewne Kara Mustafie zależało na pośpiechu, by stosunkowo szybko, a na pewno przed letnimi deszczami i nadejściem późnych jesiennych chłodów dotrzeć pod stolicę Habsburgów i dalej kontynuować kampanię już w kierunku innych części Austrii. Najprawdopodobniej podobne powody kierowały w 1529 roku sułtanem Sulejmanem II, który także nie zabrał za sobą armat-bałjemezów. Poza tym, tak samo jak potem, wiele lat później, wielki wezyr nie chciał zbyt długo oblegać Wiednia, licząc na jego poddanie.

Jednak w opinii wspomnianego kronikarza, to właśnie mówiąc oględnie, brak wyobraźni, bezgraniczna pycha i zadufanie we własne siły były tymi przyczynami, dla których Kara Mustafa mniemając, że „,państwem cesarza zawładnę bez wojny i walki” nie zabrał na wyprawę wiedeńską albo w ogóle, (albo w dostatecznej ilości) ciężkich i lżejszych dział oblężniczych o odpowiednim wagomiarze i sile niszczenia. Dziejopis osmański wymienił dokładnie liczbę posiadanych wtedy armat. Pisał zatem, co następuje:

\footnotetext{
45 Ibidem, s. 118

46 Ibidem.
} 
Ale wielki serdar nie wpadł na ten pomysł [tj. rekwizycji z pogranicznych twierdz tureckich na Węgrzech - DW] i prawa owego [zastosować] nie chciał. „Państwem cesarza zawładnę bez wojny i walki”- myślał sobie, więc wyruszył mając w obozie jedynie dziewiętnaście kolubryn strzelających pociskami trzy- do dziewięciokkowymi, pięć moździerzy do [miotania] bomb oraz sto dwadzieścia dział szahi- darbuzenów, a z tej liczby dwie kolubryny zostawił pod Jawarynem. (Mianem kolubryn określa się działa strzelające kulami trzy- do dziewięciokkowymi, bałjemezami natomiast nazywa się armaty, które miotają pociski od dziesięciu do czterdziestu okk). Czyż można jednak $z$ takich drobnych działek bombardować zamek tak potężny, a z nieprzyjacielem niemieckim rozprawiać się, nie poczyniwszy odpowiednich przygotowań? Biadaż tej zarozumiałości, biada owej bezmyślności!"47.

Według relacji Silahdara Mehmeda agi, Kara Mustafa w ogóle nie spodziewał się, że artyleria strzelająca z murów Wiednia, będzie pod względem wagomiaru znacznie przewyższać jego własną:

Później kazał on ważyć pociski armatnie, którymi nieprzyjaciel z naprzeciwka ostrzeliwał działa jego własne, oraz ubolewał i zdumiewał się nad nimi. Ale czy to mogło w czymkolwiek pomóc? ${ }^{48}$.

Zapewne to właśnie na tym przekazie oparł się Feroz Ahmad, pisząc „o zupełnym braku ciężkiej artylerii” w armii wielkiego wezyra. Zaznaczyć należy, iż inny dziejopis osmański, Husejn Hezarfenn, wyraźnie pisze o tym, że Turcy posiadali podczas oblężenia nie tylko lżejsze szahi-darbuzeny, ale i znacznie cięższe bałjemezy i moździerze. To przecież właśnie według Silahdara Mehmeda agi owych bałjemezów, absolutnie niezbędnych do ostrzału silnie umocnionych murów i bastionów wiedeńskich miało kompletnie brakować Kara Mustafie, by znacznie łatwiej mógł zdobyć miasto...

Kronikarz Husejn Hezarfenn pisał to w kontekście rady Ibrahima paszy, który zalecał wielkiemu wezyrowi wykopanie rowu, tj. okopu w którym umieszczone zostaną „na drodze giaurów” (pod Wiedeń) posiadane działa bałjemezy, moździerze i inne rodzaje armat, wszystkie oddziały janczarów, a za nimi postawione zostaną siły jazdy. Kiedy natomiast siły przeciwnika znajdą się dostatecznie blisko, jednoczesny ogień, a potem atak jazdy nie tylko zada, ,giaurom” ogromne straty, ale

Z pomocą Pana Przesławnego, wojsko muzułmańskie zwycięży i zatriumfuje, zaś wojsko giaurskie będzie rozbite i rozgromione ${ }^{49}$.

Tylko w centrum sił osmańskich dowodzonym przez wielkiego wezyra, tuż przed samą decydującą fazą bitwy miało znajdować się pięć bałjemezów ${ }^{50}$. Trudno powiedzieć wprawdzie, czy owa wspomniana ciężka artyleria znalazła się od początku w składzie wojsk osmańskich, została ewentualnie przewieziona w częściach i potem

\footnotetext{
47 Ibidem.

48 Ibidem.

49 Husejn Hezarfenn, [w:] Kara Mustafa, op. cit., s. 255.

50 Ibidem, s. 256.
} 
złożona na miejscu, czy też były to działa zdobyte już w trakcie kampanii, tj. w zamkach pogranicza węgiersko-habsburskiego, czy w samej Dolnej Austrii. O lżejszych szahi-darbuzenach, użytych w liczbie 30 jako działach typowo polowych, nadmienia wspomniany kronikarz przy okazji niewielkiego opisu w kontekście działań oddziału dowodzonego przez Huseina paszę z Damaszku ${ }^{51}$.

O znacznej liczbie 1500 artylerzystów/kanonierów-dżebedżich (tur. cebeci) i ich użyciu podczas oblężenia Wiednia wyraźnie wspomina także kronikarz Defterdar Sary Mehmed pasza, pisząc o ich dość znacznej liczbie: „,...) kiahia dżebedżich z tysiącem pięciuset dżebedżimi. Ustawiono również gęsto armaty bałjemezy, które burząc zamki i [rzucając] gromy, [sieja] przerażenie, a także moździerze, które budzą niepokój i wydają huk. Potem zaś, z całej siły zaczęto nieprzyjaciela gnębić i trapić" 52 .

Można więc postawić pytanie: jaki był rzeczywisty stosunek sił walczących stron w artylerii? W polskiej literaturze problemu jej udział po obu stronach konfliktu został już wcześniej opisany. Współczesnym źródłem pisanym jest w tym względzie zwłaszcza diariusz generała Marcina Kątskiego (1635-1710), wykorzystany przez autorów późniejszych opracowann ${ }^{53}$. Garnizon Wiednia, wzmocniony parkiem artyleryjskim z arsenałów miejskich, liczył sobie początkowo aż 312 armat (nie wydaje się, by ta liczba w toku ciężkich walk się utrzymała). Natomiast siły habsburskie posiadały jeszcze na początku września 1683 roku 70 dział. W składzie wojsk, które przyszły z odsieczą, było u Sasów ich 16, w kontyngencie frankońskim i szwabskim 12, a w bawarskim 26 sztuk. Jeśli do tego dodamy jeszcze 28 dział polskich, to łączna liczba wyniosła 152 sztuki. Przeciwko nim znalazło się 142-150 armat osmańskich ${ }^{54}$. Stosunek liczby dział o różnym wagomiarze był zatem bardzo wyrównany.

O samych zaś działaniach oblężniczych pisze zwłaszcza Dżebedżi Hasan Esiri, który nie szczędzi opisów sporządzania podkopów pod mury, skutków eksplozji podłożonych ładunków, wysokich strat w ludziach wśród sił oblężniczych. Tylko jednego dnia, według wspomnianej relacji, na odcinku dowodzonym przez Ahmeta paszę zginęło aż trzech agów dżebedżich ${ }^{55}$. Według wspomnianego kronikarza, szczególnie zacięte walki toczyły się na odcinkach nad fosą. Przyniosło to ogromne straty (w ciągu ostatnich 15 dni: „toczyła się wojna taka, jakiej podobnej nie było, a naszych [żołnierzy osmańskich] padło tylu, że okolica zamieniła się w cmentarz") ${ }^{56}$. Sam zaś Kara Mustafa jako serdar nie szczędził tym oddziałom, które walczyły na pierwszej linii swej łaskawości i dobroci a choragwiom ochotników dawat co dzień kotty pilawu i leguminy ryżowej z szafranem i miodem, tudzież wielkie ilości kawy oraz całe kiesy bak-

${ }^{51}$ Ibidem, s. 289.

52 Defterdar Sary Mehmed pasza, [w:] Kara Mustafa, op. cit., s. 288.

53 Por. M. Kątski, Diariusz wyprawy wiedeńskiej króla Jana III, red. B. Królikowski, Lublin 2003, s. 6 i n.; ponadto: G. Baumfeld, Udziat artylerii polskiej w odsieczy wiedeńskiej, „Przegląd Artyleryjski”, 11 (1933); S. Pawlina, Udziat polskiej artylerii w bitwie pod Wiedniem 1683 roku, http://www.historia. org/ 2009/ 12/ 28/5502/.

${ }^{54}$ Por. S. Pawlina, op. cit.

55 Por. DHE, [w:] Kara Mustafa, op. cit., s. 222-223.

${ }^{56}$ Ibidem, s. 222. 
$s z y s z u^{57}$. Zapewne tak było, jak informuje Dżebedżi Hasan Esiri podczas pierwszych tygodni oblężenia, bo potem zaczęły dawać znać dotkliwie o sobie problemy z zaopatrzeniem w żywność, o czym niżej.

Warto też dodać, że i załoga Wiednia nauczyła się dość skutecznie zmniejszać skutki eksplozji zakładanych przez osmańskich saperów potężnych ładunków prochowych, poprzez wykopywanie po wewnętrznej stronie murów wielu otworów. Powodowały one to, że siła wybuchu ulegała odpowiedniemu rozłożeniu, przez co rezultaty eksplozji owych min były już mniejsze, niż gdyby dotyczyło to ściśle zamkniętej przestrzeni w podkopach, mogącej spowodować zawalenie się całych obszernych fragmentów obwarowań, co zupełnie uniemożliwiłoby ich skuteczną obronę. Poza tym, siłę detonacji min tureckich osłabiała także grubość murów wiedeńskich bastionów i fortów, które nie poddawały się jej tak łatwo, jak chcieliby tego muzułmańscy minerzy i artylerzyści ${ }^{58}$.

Podobne metody zdobycia miasta i prowadzenia działań oblężniczych przy pomocy rycia przez górników chodników pod murami i detonacji zakładanych ładunków prochowych, określanych jako miny, przy poszczególnych bastionach, opisał także kilkakrotnie wspomniany już Silahdar Mehmed aga ${ }^{59}$. Według tego kronikarza, między oddziałami prowadzącymi podkopy, a oblężonymi dochodziło do zaciekłych starć przy użyciu wystrzeliwanych ,bomb burzących” i ,wielkich granatów”. Owe „środki walki” używane przez poszczególne siły osmańskie miały podobno zadać dosyć znaczne straty ,giaurskim przeklętnikom"60.

Brak większej ilości ciężkich dział, przynajmniej częściowo, rekompensowała duża liczba bardzo dobrych inżynierów osmańskich. Ten fakt wskazał m.in. wspomniany J. Stoye:

\footnotetext{
Chrześcijańscy inżynierowie, którzy później oglądali to miejsce [tj. wysuniętą do przodu ufortyfikowaną bazę Kara Mustafy, w ogrodzie Trautsona, umożliwiającą mu bezpośredni dostęp do okopów], wyrażali niekłamany podziw dla rozplanowania konstrukcji tureckich prac oblężniczych Stwierdzili, że przy zdumiewającej komplikacji wykonania, cały system aproszy i równoległych połączeń w podziwu godny sposób pasował do ukształtowania terenu. Aprosze prowadziły mniej lub bardziej bezpośrednio przez glacisy w kierunku trzech wystających katów przeciwskarpowych przed bastionem zamkowym, tamtejszym rawelinem oraz bastionem Lőbel ${ }^{61}$.
}

Zatem nie można całkiem odmówić Kara Mustafie wyobraźni i kompletnego braku pojęcia o możliwościach prowadzenia oblężenia tak potężnych obwarowań jak wiedeńskie.

Ustalenia dwóch wybitnych znawców problematyki dziejów Turcji osmańskiej wcześniej Zygmunta Abrahamowicza (1923-1990), a w ostatnich latach Dariusza

\footnotetext{
57 Ibidem.

58 Por. DHE, op. cit., s. 22..

59 Por. SMaF, op. cit., s. 152-154.

60 Ibidem.

61 Por. J. Stoye, op. cit., s. 162.
} 
Kołodziejczyka pozwalają na przynajmniej częściowe zrozumienie dla tureckiego sposobu prowadzenia działań bojowych, zmierzających do zdobycia stolicy Habsburgów. W wywiadzie umieszczonym na portalu internetowym Stowarzyszenia Filmowców Polskich, Dariusz Kołodziejczyk, mówi co następuje:

\begin{abstract}
Drugą przyczyną wyprawy na Wiedeń była chęć podreperowania osmańskiego budżetu. Turcy wierzyli, że w Wiedniu znajduje się skarbiec Habsburgów i chcieli go zdobyć. Warto przypomnieć, jak polski historyk, orientalista Zygmunt Abrahamowicz thumaczył, dlaczego Kara Mustafa tak zwlekał z tureckim szturmem generalnym na miasto: Turcy oblegli Wiedeń już w lipcu, a bitwa była we wrześniu. Przy ówczesnej tureckiej technice wojskowej, a mieli wtedy najlepszych saperów na świecie i niezłą artylerię, mogli do Wiednia po prostu wejść. Nie weszli, bo Kara Mustafa liczył na to, że Wiedeń się podda, a to się opłacało. Tradycja armii tureckiej polegała na tym, że miasto zdobyte szturmem przez trzy dni należy do janczarów: mają prawo palić, gwałcić i rabować, a dopiero to co zostaje, przypada imperium. $Z$ tego powodu Kara Mustafa od początku proponował honorowe warunki kapitulacji i pewnie Wiedeń by się poddał, gdyby nie Jerzy Franciszek Kulczycki, który się przedarł - tego nie wykorzystano w filmie, a to bardzo filmowa scena - i obrońcy wiedzieli, że warto wytrwaćc ${ }^{2}$.
\end{abstract}

Podobną wykładnię problemu przyjmuje także inny polski historyk i badacz wojskowości XVII wieku, Mirosław Nagielski, który zresztą powołuje się na ustalenia Dariusza Kołodziejczyka, jako tego, który zna wspótczesne źródta tureckie ${ }^{63}$.

Tu wydaje się jednak, że problem szybkiego poddania miasta, bądź ewentualnej kapitulacji załogi jest nieco bardziej złożony. Nawoływanie do poddania się i przyjęcie ,prawdziwej wiary” leżało od wieków w tradycji prowadzenia wojen przez wyznawców islamu, zgodnie zresztą z zasadą nawracania i misyjności, zwaną po arabsku dawa. Jej elementem był w tym wypadku dwa listy Kara Mustafy: do ludności miasta Sopron i do dowództwa i ludności miasta Wiedeń (oba opublikowane w cytowanym zbiorze źródeł opracowanym przez Z $\mathrm{Z}$. Abrahamowicza ${ }^{64}$. O liście wielkiego wezyra do Wiedeńczyków, nakłaniającym ich do poddania się wspomina także Silahdar Mehmed aga, a posłańcem, który owo pismo im dostarczył był Ahmet aga, dowódca formacji delich, który niedługo potem zginął ,śmiercią męczeńską” (według muzułmanów) od postrzału w głowę ${ }^{65}$.

W pierwszym, kierowanym do mieszkańców Sopronu, wzywa ich do poddania się władzy Emeryka Thőkőlyego i przede wszystkim przyjęcia władzy sułtańskiej. Obiecuje jednocześnie „spokój i bezpieczeństwo - wam, waszym żonom, waszemu mieniu i zapasom żywności i posiadłościom, którym żadna krzywda się nie stanie". Odrzucenie warunków poddania miało natomiast przynieść ,zionący ogniem gniew padyszacha i wyrżnięcie wszystkich szablami”. Dalej wielki wezyr pisze o tym, że wasze rodziny pójda w jasyr, a wy sami (tj. mężczyźni-patrycjusze miasta) będziecie

${ }^{62}$ Por. Wielka bitwa o wiarę, op. cit.

${ }^{63}$ Por. Czy warto było iść pod Wiedeń?, op. cit., s. 8.

${ }^{64}$ Por. Kara Mustafa do ludności miasta Sopron; Kara Mustafa pasza do dowództwa i ludności Wiednia, [w:] Kara Mustafa pod Wiedniem, op. cit., s. 327-329.

${ }^{65} \mathrm{SMaF}$, op. cit., s. 116-117. 
zakuci $w$ łańcuchy $i$ kajdany, miasto wasze zostanie zagrabione $i$ złupione, a domostwa wasze puszczone z dymem ${ }^{66}$. Podobny ton miał drugi z listów do mieszkańców Wiednia. Kara Mustafa proponował nie tylko poddanie się Wiedeńczykom, ale także przyjęcie przez nich islamu, co według zasad Proroka i jego religii ma zagwarantować im ocalenie i zabezpieczenie przez wszelkimi krzywdami, a każdy, kto chce miasto opuścić, będzie mógł to bez problemu uczynić67. Pismo wezyrskie zostało doręczone przez jednego z tureckich agów i wręczone żołnierzowi pochodzącemu z Chorwacji, a ten przekazał je komendantowi Wiednia. Jednak Ernst Rüdiger Starhemberg miał szorstko odprawić posłańca i kontynuował zamurowywanie bram miejskich. Zatem, Kara Mustafa kazat przemówić działom ${ }^{68}$.

Niewatpliwie, najbardziej optymalnym rozwiązaniem dla Osmanów było przyjęcie przez wielkiego wezyra kapitulacji dowództwa miasta i przejęcie go w stanie pozbawionym zniszczeń wojennych i nadal zasobnego (w przypadku oddania Wiednia do łupienia janczarom i innym askerom na trzy dni, niewiele by już tam zostało!). To przydawałoby jeszcze większemu splendoru zwycięzcy i bardzo bogate dochody w przyszłości. Sun Tzu pisał kiedyś, że „największym zwycięstwem jest zwycięstwo odniesione bez wojny". Jak wiadomo, Wiedeń zaczął długotrwałą obronę, mimo tego, iż miasto nie było dostatecznie przygotowane do walki i oblężenia pod względem ilości załogi, zaopatrzenia w żywność i w środki walki. Zadecydowała o tym przede wszystkim wola działania i ogromna odwaga komendanta E. R. Starhemberga.

Stąd też Kara Mustafa został, więc, niejako zmuszony do podjęcia działań o charakterze wojny pozycyjnej i zastosowania techniki oblężniczej, w tym kopania podziemnych chodników i zakładania oraz odpalania min. Nie można jednak w żadnym razie twierdzić, że armia osmańska nie była kompletnie do podobnych działań przygotowana. Co najwyżej, ciężkich dział burzących mogło być zbyt mało, podobnie jak artylerii w ogóle. Możliwe, zatem, że wielki wezyr, w obawie przed zbyt dużą ilością ciężkich armat, które opóźniałyby marsz jego armii nie zabrał ich w dostatecznej ilości, podobnie rzecz się miała z lżejszą artylerią. Najprawdopodobniej także nie spodziewał się, że skutki działania min i odpalanych ładunków na skutek oporu i determinacji obrońców nie przyniosą jednak spodziewanych rezultatów. Tak, czy inaczej, w razie braku odsieczy odpowiednich rozmiarów i zbyt przedłużającego się oblężenia, stolica Habsburgów była nieuchronnie narażona na upadek i zniszczenie.

Nie wydaje się też, że Kara Mustafa okazał się kompletnym dyletantem pod względem militarnym i jako taki, z góry był skazany na klęskę. Armia osmańska, mimo pewnych opóźnień dość sprawnie dotarła pod Wiedeń i zamknęła pierścień oblężenia. O umiejętnościach wielkiego wezyra świadczy też dobór wyższych dowódców i przede wszystkich obecność inżynierów, saperów i licznych artylerzystów. Z punktu widzenia strategii słuszną wydaje się decyzja skoncentrowania na celu głównym, przy jednoczesnym pozostawieniem na tyłach ponad 20-tysięcznego korpusu Ibrahima pa-

\footnotetext{
66 Kara Mustafa do ludności, op. cit., s. 327.

67 Ibidem, s. 328-329.

68 Por. J. Stoye, op. cit., s. 157.
} 
szy pod Jawarynem. Było to na tyle niedaleko (niecały dzień drogi), że pozostała po walkach o tę twierdzę część jego wojsk mogła potem dotrzeć pod Wiedeń i ostatecznie wziąć udział w bitwie.

Niewątpliwie, wielki wezyr był człowiekiem bardzo ambitnym, żądnym władzy i niekiedy przekonanym o swym monopolu na rację (tu choćby mało chwalebny spór ze wspomnianym Ibrahimem paszą). Na pewno też był człowiekiem odważnym i nie cofającym się przed ryzykiem (niekiedy zbyt nadmiernym). Dla znacznej części wyższych dowódców tureckich, którzy chcieli zdobyć cele bliższe, tj. pierwotnie zakładane - Jawaryn i Komarno, wezyrski plan pójścia znacznie dalej na zachód, wydawał się nie mieć podstaw, bo ich zdaniem, wojska sułtańskie nie były do tak szeroko zakrojonej ofensywy przygotowane.

Kara Mustafa był dobrym wodzem, walczył jednak z najlepszymi dowódcami swych czasów - Karolem Lotaryńskim, a przede wszystkim królem Janem III, który był chyba najlepszym w Europie znawcą osmańskiej i tatarskiej sztuki wojennej. Decyzja marszu pod Wiedeń była ryzykowna, ale przebieg działań ukazał, że upadek stolicy Habsburgów był jednak już tylko kwestią kilku dni. Jak pisał przecież O. Forst de Battaglia - Turcy zbliżyli się na odlegtość strzału muszkietowego od pałacu cesarskiego ${ }^{69}$. Poza tym wyczerpanie środków walki i sił obrońców także było już bardzo bliskie i tylko wiadomości od nadciaggającej odsieczy i żelazna wola komendanta Starhemberga pozwoliły na utrzymanie wśród nich ducha oporu. Poza tym, pod względem psychologicznym, Kara Mustafa zbyt mocno uwierzył w utrwalone przez siebie schematy myślowe o niemożności odsieczy, a tym bardziej szybkiego pojawienia się w niej armii Sobieskiego, nie mówiąc już o przejściu przez nią obszaru wzniesień Lasu Wiedeńskiego (Wiener Wald). Działania wezyra na tym kierunku okazały się zbyt późne i nie zapobiegły klęsce jego armii.

Na usprawiedliwienie Kara Mustafy można dodać, że nie tylko on, ale i chyba nikt inny nie wierzył w szybkie pokonanie $\mathrm{w}$ tak trudnym terenie skoncentrowanych i okopanych tam bardzo licznych sił janczarów i innych formacji (zwłaszcza broniących wsi Kahlenbergerdőrfel, Nussdorf i Dőbling, czy wzniesień Nussberg i Krapfenwaldl). Dopiero po ich wyparciu (i częściowym zniszczeniu) było możliwe przeprowadzenie intensywnego ostrzału artyleryjskiego, który przyniósł duże straty $\mathrm{Osmanom}^{70}$. Decydującym epizodem była aż 20-tysięczna szarża jazdy (zwłaszcza ponad 2 tysięcy polskich husarzy) ze zboczy góry Kahlenberg ${ }^{71}$. To jak wiadomo, zakończyło się pogromem armii osmańskiej i zajęciem jej ogromnego obozu. Poza tym, wielki wezyr uważał, że Rzeczpospolita absolutnie nie złamie warunków traktatu z Żurawna z 1676 roku (ratyfikowanego w 1679 r.), co zostało potraktowane przez, Turków jako „wielkie wiarołomstwo" ${ }^{2}$. Lata potem, jeden z najwybitniejszych wodzów w dziejach świata, cesarz Napoleon mówił o tym, że słowo „niemożli-

\footnotetext{
69 Por. O. Forst de Battaglia, op. cit., s. 213.

70 SMaF, op. cit., s. 162; J. Wimmer, Wiedeń 1683, op. cit., s. 316-324.

71 SMaF, s. 161-162. O przebiegu tej fazy bitwy por. szczegółowo J. Wimmer, op. cit., s. 325-340.

72 Por. O. Forst de Battaglia, op. cit., s. 188.
} 
we” trzeba wyrzucić ze wszystkich słowników. „Niemożliwym” według sztabowców francuskich było także sforsowanie Ardenów przez siły pancerne i zmechanizowane III Rzeszy w 1940 roku, co znacząco wpłynęło na nieodległą klęskę Francuzów. Jeszcze bardziej szalone wydawało się spalenie okrętów przez Hernana Cortésa, by udaremnić jakąkolwiek myśl o odwrocie jego niewielkich liczebnie sił w marszu na ogromny Tenochtitlan i przeważające siły Azteków, czy potem wyprawa Francisca Pizarro na podbój państwa Inków. Jednym słowem, na wojnie ryzyko czasem przynosi ogromny sukces, może jednak przynieść także spektakularną klęskę, co udowodnił Kara Mustafa zupełnie nie licząc się z aż tak zaciętym oporem załogi Wiednia, a tym bardziej nadejściem silnej odsieczy dla oblężonej stolicy i udziale w niej króla Jana III.

Na koniec, w znaczącym stopniu skuteczność działania armii osmańskiej spowolnił coraz bardziej widoczny brak żywności i aprowizacji, co było efektem wcześniejszego, straszliwego marnotrawstwa wszelkiej zdobyczy, bezmyślnego pustoszenia i grabieży zajętych ziem habsburskich. To potem fatalnie się obróciło na niekorzyść Turków, o czym, piszą wyraźnie kronikarze osmańscy, w tym zwłaszcza Dżebedzi Hasan Esiri ${ }^{73}$. Był to także jeden z elementów, który fatalnie zadziałał na zdolności bojowe armii Kara Mustafy i doprowadził do jej częściowego rozproszenia. Autor ten wskazuje również na masowe przypadki demoralizacji obyczajowej i upadku dyscypliny oraz „grzechu pychy”, który powodował, że mimo braku zwycięstwa, już zaczęto dzielić zdobyte ziemie i zamki, co powodowało liczne konflikty między najeźdźcami $^{74}$.

Turcy już zaczęli je uważać za swoje ,na zawsze” i przez swą butę byli pewni zwycięstwa. W podobnych nastrojach pewnego ,wielkiego zwycięstwa” utwierdzali Kara Mustafę także liczni pochlebcy, kronikarz jednak dodaje, że wielu z jego dowódców „było niechętnych nadmiernemu wzrostowi władzy prześwietnego serdara, stąd też niekiedy celowo wprowadzano go w błąd na temat rzeczywistego obrazu sytuacji, po to by jego samego wprowadzać w zaślepienie i pychę"75. Oprócz tego, wojska wielkiego wezyra zaczęła trapić plaga rozprzężenia wewnętrznego i masowych dezercji, nawet i wśród samych janczarów, co spowodowało olbrzymi chaos. Także bardzo duża część wojska, po zdobyciu ogromnych łupów, chciała je przede wszystkim zachować, stąd tysiące żołnierzy różnych formacji, zanim jeszcze dotarło do Austrii, sa-

73 DHE, op. cit., s. 217-218: W miejscowościach po drodze z Jawaryna do Wiednia, gdzie urzadzono postoje, błakaty się między namiotami - ryczac, beczqc i meczac - krowy, owce i kozy, jedne mleczne - inne bez mleka. Ludzie doili je, a potem szli dalej, jeśli jednak komuś zachciało się mięsa, tedy zarzynat którq́ś sztukę i część spożywat, a rano, kiedy zbierano się $w$ droge, porzuciwszy resztę, odjeżḋat. Nad rzekq Fischa [...] wznosi się po obu jej stronach piękny zamek z ogromnym podgrodziem. Po turecku zwano go zamkiem Merdżan. Nad owa to rzeka stało więcej niż sto młynów, więc byty tam olbrzymie spichrze skarbowe, a w spichrzach tych zgromadzono setki tysięcy kile maki i paszy na potrzeby wojska [...] Tatarzy zdobyli również $i$ ten zamek oraz złupili znajdujace się tam dostatki i zapasy żywności, po czym zamek, podgrodzie i owe spichrze, wraz z całym mnóstwem żywności spalili.

74 Ibidem, s. 218.

75 Ibidem 
mowolnie wracało na osmańskie Węgry. Tak też, według kronikarza zdezerterowały tylko spod Jawaryna „setki tysięcy” ludzi (sic!), do tego stopnia, że „w okopach nie pozostało nawet dziesięć tysięcy"76. Zjawisko masowych dezercji nasiliło się wraz z przedłużającym się oblężeniem Wiednia, wydatnie zmniejszając ilość sił osmańskich zdolnych do walki.

\section{WSPÓŁCZESNE SĄDY I KONTROWERSJE DOTYCZĄCE ZNACZENIA BITWY POD WIEDNIEM I CELOWOŚCI POLSKIEJ ODSIECZY, CZY POLITYCZNEGO I MILITARNEGO WSPARCIA HABSBURGÓW}

Skala zwycięstwa pod Wiedniem, a zwłaszcza rola Jana III Sobieskiego i triumfu jego strategii znalazła ogromny rezonans, tak w relacjach mu współczesnych, jak i w jego obchodach w czasach późniejszych, podczas zaborów, czy w latach II Rzeczypospolitej. W ostatnich latach problem ten przedstawił w niewielkiej objętościowo, lecz dość cennej pracy Michał Rożek ${ }^{77}$. Na tradycję obchodzenia kolejnych rocznic wiktorii wiedeńskiej w Rzeczypospolitej, i to jeszcze od 1684 roku zwrócił uwagę ostatnio także Wojciech Duda-Dudkiewicz w swym artykule. We wspomnianej publikacji autor zajął się analizą owego święta i daty kolejnych obchodów tak w Krakowie, jak i w 100-lecie bitwy w samym Wiedniu. W czasach stanisławowskich jej uczczeniem było odsłonięcie w 1788 roku w Warszawie pomnika króla Jana III, co spotkało się jednak ze złośliwymi komentarzami i opiniami, wypadającymi na niekorzyść Stanisława Augusta Poniatowskiego ${ }^{78}$. Szczególnie uroczyste obchody zorganizowane zostały w 200-lecie bitwy wiedeńskiej (1883) w Krakowie, będącym wówczas jednym $\mathrm{z}$ głównych miast zaboru austriackiego (z udziałem bardzo wielu znamienitych gości, a cała impreza zbiegła się z 25-leciem pracy artystycznej Jana Matejki, który ofiarował wówczas obraz swego autorstwa, znany potem powszechnie jako Sobieski pod Wiedniem ${ }^{79}$. Rocznica ta była jednocześnie okazją do wizyty delegacji polskiej w Watykanie u papieża Leona XIII, który podjął ją z ceremoniałem należnym oficjalnej delegacji państwowej. Owo zamanifestowanie z dużym rozgłosem istnienia Polski wśród narodów Europy miało bardzo istotną wymowę w czasie gdy sprawa polska znikała z porządku dziennego gabinetów dyplomatycznych. Jak potem podkreślano, była to ważna manifestacja obecności Polski po upadku powstania styczniowego ${ }^{80}$.

\footnotetext{
76 Ibidem, s. 218-219.

77 Por. szerzej na ten temat M. Rożek, Zwycięstwo Jana III Sobieskiego pod Wiedniem. Echa wiktorii, Kraków 2008, s. 11 i n.

78 Por. W. Duda-Dudkiewicz, „Była solemna procesyja...”. Pamięć o wiktorii wiedeńskiej, „W Sieci Historii. Triumf wiedeński”, Nr 5 (05), wrzesień-październik 2013, s. 21.

${ }^{79}$ Por. W. Duda-Dudkiewicz, op. cit., s. 22. Echem 200-lecia tej rocznicy była też m.in. wydana praca, autorstwa J. Danielewskiego, Król polski ratuje Niemcy i chrześcijaństwo. Opis Odsieczy Wiedeńskiej przez Jana III Sobieskiego dnia 12 września 1683 roku, Toruń 1883.

${ }^{80}$ Por. W. Duda-Dudkiewicz, op. cit., s. 22-23.
} 
Kolejna, 250-rocznica odbywała się w październiku 1933 roku, już w niepodległej Polsce. Równolegle do uroczystości odbywających się w kraju, miała miejsce m.in. uroczysta msza z udziałem prymasa Polski, kardynała Augusta Hlonda na wzgórzu Kahlenberg, podczas której widoczne były bardzo liczne sztandary polskie i austriackie. Punktem kulminacyjnym była jednak odbyta w Krakowie na Błoniach wielka defilada oddziałów kawalerii, a podczas imprezy, na wieżach kościelnych odezwały się dzwony. W obchodach uczestniczył prezydent Ignacy Mościcki, marszałek Józef Piłsudski, wraz z bardzo licznie przybyłą generalicją i innymi oficerami Wojska Polskiego. Istotnym elementem obchodów 250-lecia bitwy była wizyta delegacji z prezydentem i marszałkiem Piłsudskim na Wawelu przy grobie Jana III i wygłoszona przez Marszałka laudacja na cześć króla i zwycięstwa wiedeńskiego. Natomiast podczas uroczystego rautu, wydanego wieczorem przez prezydenta Mościckiego, oprócz toastu za jazdę polską, wzniesiono też toast na chwałę Turcji, w dowód wdzięczności za jej postawę wobec sprawy polskiej w epoce porozbiorowej ${ }^{81}$.

Kolejna rocznica, 300-lecia bitwy wiedeńskiej była obchodzona w czasach schyłkowego PRL. Władze partyjno-państwowe, zwłaszcza po 1956 roku otwarcie nie zwalczały pamięci o tym doniosłym fakcie, lecz podczas obchodów bardzo wystrzegano się akcentowania jej aspektów religijnych. Niewątpliwie, wspomniana rocznica doczekała się licznych imprez, jak również publikacji. Jej skala była jednak nieporównywalna ani do 1883 roku, ani do 1933 roku. Jak wskazał W. Duda-Dudkiewicz:

Nad uroczystościami zorganizowanymi przez komunistów na Wawelu unosiła się atmosfera zawieszonego kilka tygodni wcześniej stanu wojennego. Polaków niespecjalnie cieszył zainscenizowany wjazd Jana III do Krakowa, ani dzwon Zygmunta bijący, gdy Jaruzelski i [Henryk] Jabłoński [ówczesny przewodniczący Rady Państwa - DW] składali kwiaty w krypcie św. Leonarda. Wielu jednak przyciągnęła i cieszyła wystawa poświęcona Wiktorii Wiedeńskiej, zorganizowana w szesnastu salach na Wawelu ${ }^{82}$.

Natomiast, jak dalej pisał wspomniany autor, już tylko nieliczni mogli zobaczyć ekspozycję w Watykanie, otwartą osobiście przez papieża Jana Pawła II, gdzie pokazany został zwiedzającym słynny list Sobieskiego do papieża Innocentego XI, zaczynający się od słów Venimus, vidimus, Deus vicit! (Przybyliśmy, zobaczyliśmy, Bóg zwyciężył!"). ${ }^{83} \mathrm{Z}$ bardzo licznie wówczas wydanej literatury rocznicowej można wymienić m.in. znakomicie wydany pod względem edytorskim (jak na tamte czasy), bardzo bogato ilustrowany album zawierający zbiór relacji i dokumentów poświęconych wiktorii wiedeńskiej, a także szereg książek i artykułów ${ }^{84}$.

${ }^{81}$ Ibidem, s. 23.

82 Ibidem.

83 Ibidem.

${ }^{84}$ Por. Venimus, Vidimus, Deus vicit. Wiktoria wiedeńska 1683 roku w relacjach i dokumentach z epo$k i$, Opr. M. Nagielski, wstęp T. Wasilewski, Warszawa 1984 (dalej jako VVDV); T. Wasilewski, Odgłosy odsieczy wiedeńskiej w Rzeczypospolitej Obojga Narodów i Z. Abrahamowicz, Tto wyprawy wiedeńskiej Kara Mustafy, „Kwartalnik Historyczny”, R. 90/1, Warszawa 1983, s. 5-54. Część książek, wówczas opublikowanych została wymieniona zwłaszcza w przyp. 2 i 4 obecnego studium. 
Mirosław Nagielski wskazuje na zalety wyprawy wiedeńskiej i polskiego udziału w niej. Według tego znanego historyka, niewątpliwie korzystnym faktem było to, że Rzeczpospolita nie toczyła wojny z Turcją samotnie, a była to wojna koalicyjna, jeszcze bardziej korzystnym było to, że jej główny ciężar spadł na Habsburgów ${ }^{85}$. Nie uważa on także, by uczestnictwo Rzeczypospolitej w Lidze Świętej było błędem, poza tym, wyprawy na Mołdawię, podjęte w roku 1684 i następnie w latach 1685-1686 związały część sił osmańskich, umożliwiając sukcesy armii austriackiej na Bałkanach ${ }^{86}$.

Dalej jednak wskazuje na wady polskiego zaangażowania pod Wiedniem, tj. dotkliwy ciężar finansowy, jakim było wystawienie prawie 35-tysięcznej armii (z czego nieco ponad 20 tysięcy znalazło się pod austriacką stolica). Kosztowało to skarb Rzeczypospolitej, według wyliczeń Jana Wimmera, na które powołuje się wspomniany historyk, aż 11 milionów złotych polskich, co stanowiło praktycznie niemal roczny dochód państwa. Bezpośrednie koszty to około 8 milionów wydanych przez Koronę, a 3 przez Wielkie Księstwo Litewskie, bo 22\% wyniosły dotacje habsburska i papieska. Jednak wymownym był fakt, że całkowite dochody państwa to 10-11 milionów rocznie. Było to tym bardziej dokuczliwe dla skarbu, że z owych długów państwo polskie już nigdy się nie wydobyło, poza tym ,zadatkowano służbę, ale nigdy nie wypłacono wojsku $100 \%$ należności" 87 .

Na współczesne nieścisłości, czy nawet ewidentne przekłamania dotyczące polskiego wkładu w zwycięstwo wiedeńskie, zwrócił w ostatnich latach znany badacz dziejów husarii, Radosław Sikora. Zakwestionował on nie tylko dawniejsze tezy i opinie pomniejszające rolę wojsk Jana III Sobieskiego w tej bitwie, a wzmacniające wkład i udział armii habsburskiej, ale przede wszystkim bardzo krytycznie odniósł się do poglądów i sądów lansowanych w ostatnich latach przez ukraińskiego historyka, Tarasa Czuchłyba, doktora habilitowanego i pracownika naukowego Narodowej Akademii Nauk Ukrainy ${ }^{88}$. Tenże badacz, autor pracy Wiedeń 1683. Ukraina - Ruś $w$ bitwie o Złote Jabłko, prezentuje tam pogląd jakoby 2/3 sił Sobieskiego w kam-

85 Jan III bardzo obawiał się, że Rzeczpospolita zostanie sama politycznie i militarnie, w obliczu klęski habsburskiej i kolejnej ofensywy osmańskiej. Dowodem na to jest jego list do hetmana polnego Mikołaja Sieniawskiego z 28 lipca 1683 roku, por. VVDV, op. cit., s. 48: Lubo Wiedeń zginie, lubo się obroni, wszystko to nam nie na rękę będzie, bo lepiej w cudzej ziemi, o cudzym chlebie, w asystencyjej wszystkich sit Imperii, nie tylko samego cesarza wojować, aniżeli samym się bronić i o swym chlebie, i kiedy nas jeszcze przyjaciele $i$ sasiedzi odstapiq, gdy im w takim razie prędkiego nie damy succursu.

${ }^{86}$ Por. Czy warto byto iść pod Wiedeń?, op. cit., s. 9: Jednq rzecz udało się załatwić- rozpoczqć wojnę z Turcja w towarzystwie innych. Badźmy szczerzy - główny ciężar tej wojny spoczat na Habsburgach [...] Uważam że było warto iść pod Wiedeń. Sobieski nie tylko wygrat bitwe, która uczyniła go sławnym, ale tez zrealizowat swój plan, bo znalazt się w centrum wydarzeń, a nie na uboczu. Potem próbowat koordynować działania ze stronq austriacka, ale ona robiła swoje. Wiażac sity tureckie na flance mołdawskiej, umożliwiliśmy Habsburgom dalsze sukcesy na Bałkanach. Mimo to, nie uważam, aby uczestnictwo Rzeczypospolitej w Lidze Świętej było błędem. Po pierwsze, nie byliśmy osamotnieni. Po drugie, były szanse odzyskać Kamieniec Podolski.

87 Ibidem.

${ }^{88}$ Por. Radosław Sikora, Wiedeń 1683. Między propagandq a faktami, „W Sieci Historii. Triumf wiedeński”, Nr 5 (05), wrzesień-październik 2013, s. 18-19. 
panii wiedeńskiej było złożone z Ukraińców ${ }^{89}$. Radosław Sikora stara się je obalić, wskazując na niuanse i zakres ówcześnie stosowanych pojęć, takich jak „Ukrainiec” i „Rusin”, zasięg granic XVII-wiecznej Ukrainy i przede wszystkim kluczowy fakt, iż wcale nie było oczywistym, że np. wojewoda ruski mobilizując dany oddział, musiał to czynić tylko z województwa ruskiego. Podobnie jak zdaniem R. Sikory, bardzo kontrowersyjnym poglądem ukraińskiego historyka jest i to, że żołnierze z poszczególnych oddziałów pochodzili tylko z tych terenów, gdzie ich rotmistrzowie sprawowali urząd ${ }^{90}$.

Istniejące już dawniej spory i kontrowersje dotyczące celowości polskiego udziału pod Wiedniem i tym samym ,uratowania Austrii” (jako przyszłego państwa zaborczego), nadspodziewanie dowiodły, że są wciąż żywe także w ostatnich latach, a nawet dziś. Ich podłoże jest tłumaczone zazwyczaj tym, że idąc z odsieczą Wiedniowi i Austriakom, Jan III Sobieski zaniedbał ,,polskie żywotne interesy”, jak np. przejęcie z powrotem, w sojuszu z Francją, pod polską suwerenność Prus Książęcych (niezależnych od 1657 roku), „niepotrzebnie też złamał traktat pokojowy z 1676 roku z Żurawna”, czy wreszcie decyzja o marszu na pomoc Austrii była zupełnie niezgodna z polskim rozumieniem racji stanu, czy „Realpolitik" ${ }^{\text {. }}$. Dodać należy, że owe krytyczne opinie i sądy nie wiążą się z istniejącymi dziś głębokimi podziałami ideowymi i światopoglądowymi między prawica, a lewicą, bo ich autorzy reprezentują różne orientacje i stanowiska w tym względzie.

Jednym z takich przykładów może być opinia znanego prawicowego publicysty i pisarza, Rafała A. Ziemkiewicza, który przy okazji piętnowania polskiego poświęcenia w ostatnich stuleciach dla obcej sprawy, narażało na szwank nie tylko interes Polski, ale przynosiło potem brak rewanżu i obojętność, czy niechęć wobec jakiejkolwiek pomocy dla sprawy polskiej, (nie mówiąc o Austrii jako państwie, które miało współudział w rozbiorach). Tytuł tej niewielkiej objętościowo publikacji wydanej w sierpniu 2012 r. jest dość wymowny - „Polska frajerem narodów”, a rzeczywiste wypełnienie sojuszu z Austrią w 1683 roku przez króla Jana III, ów autor nazywa wprost „,tępą lojalnością”, która służyła temu m.in. by Rzeczpospolita „wykrwawiała Turcję i siebie samą w interesie habsburskim"92.

89 Ibidem.

90 Ibidem, s. 19. Można jedynie dodać, że podczas konferencji odbytej w siedzibie polskiej ambasady w Kijowie, delegacja polska (M. Nagielski, Z. Hundert i R. Sikora) całkowicie zdezawuowała poglądy T. Czuchłyba. Wspomniany autor, mimo zaproszenia, w ogóle nie zjawił się podczas obrad panelu.

91 Podobne poglądy zebrał w ostatnich latach m.in. Jan M. Długosz w tygodniku „Polityka” w rocznicowym artykule z 2013 roku, por. idem: Dlaczego Jan Sobieski bit się z Turkami?, http://www.polityka. pl/ tygodnikpolityka/historia1555095,1,rocznica-bitwy-pod-wiedniem...

92 Por. R. A. Ziemkiewicz, Polska frajerem narodów, http://www.historia.uważamrze.pl/ artykul/ 924810.html? print=tak\&p=0: Trzeba by wreszcie napisać ksiażkę - a byłoby to niestety dzieło dość obszerne - o ciagłym wodzeniu Polaków za nos. Trzeba by ja chyba zaczqć od Jana III Sobieskiego, jak w interesie Austrii walczyt przez większość swego życia z Turcja. Zyskał nam w ten sposób sławę obrońców chrześcijaństwa na którq nikt inny się jakoś nie łaszczyt i położyt podwaliny pod rozbiory. Zasługuje na prawdziwy podziw tępa lojalność, że nasz król wywiazywat się z sojuszu z podpuszczajaca go do kolejnych wypraw na Mołdawię Austriq - choć cesarz z przyrzeczonej pomocy ani razu nie przysłat, a wręcz 
Z opinii przedstawionych przez intelektualistów, a zarazem ludzi mediów, krytycznych wobec polityki Jana III wobec Turcji i samej wyprawy wiedeńskiej, chyba jedną z najdalej idących jest felieton Ludwika Stommy. Autor, znany od dawna jako zwolennik lewicy i felietonista tygodnika „Polityka”, całkowicie zakwestionował celowość podjęcia przez króla wojny z Osmanami w 1683 jako de facto zupełnie zbędnej politycznie i w ogóle nieprzydatnej. L. Stomma, powołał się także na opinię znanego badacza dziejów tureckich, Jana Reychmana o ówczesnej słabości Imperium Osmańskiego, które mogło wprawdzie zdobyć Wiedeń, ale utrzymać go już nie było w stanie, poza tym, reprezentowało jedynie „pozorną świetność”, a w rzeczywistości było pokonywane na lądzie i morzu przez Austriaków i Wenecjan, zmagało się z rosnącymi problemami gospodarczymi, słowem było państwem w przededniu zupełnego upadku. Co za tym idzie, zdaniem L. Stommy na który można było chyba ,jedynie trochę poczekać", bez zbędnego zaangażowania w kompletnie chybioną politycznie, polską odsiecz Wiednia ${ }^{93}$. Wprawdzie wspomniany J. Reychman nic podobnego w swej „Historii Turcji” nie napisał, ale to tym gorzej dla faktów...

Według tego autora, słaba była również armia turecka, która w 1672 r. (po raz kolejny w 1675 r.) nie była w stanie nawet zdobyć Lwowa. Podobnie rzecz się miała z siłami Kara Mustafy, które choć podeszły pod mury Wiednia, to utrzymać go nie były w stanie, w razie jego zdobycia, o dalszej ekspansji już nie wspominając ${ }^{94}$. Kolejne sądy felietonisty „Polityki” idą znacznie dalej, a jego zapał w ukazywaniu braku wyobraźni i krytyce polityki króla jako chyba, jego zdaniem, zbyt gorliwego obrońcy chrześcijaństwa poszedł w radykalizmie sądów bardzo daleko. L. Stomma powołuje się także na jakichś bliżej nieokreślonych historyków, widocznych krytyków polityki Sobieskiego, który zdając sobie sprawę ze stanu państwa osmańskiego, tj. jego głębokiego kryzysu, wbrew polskiemu interesowi, zbrojnie wspomógł niechętnych Rzeczypospolitej Habsburgów. Stara się także dociec przyczyn marszu sił polskich pod Wiedeń, widząc w tym przede wszystkim chęć wzmocnienia przez zwycięstwo swej pozycji w państwie wobec szlachty i magnaterii ${ }^{95}$.

dyskretnie przeszkadzat ( $w$ końcu miat interes $w$ tym, by Polska wykrwawiata Turcje $i$ siebie sama, nie żeby się zdobyczami na niej wzmocniła). Przyrzeczona królewiczowi Jakubowi córkę wydat za elektora bawarskiego.

93 Por. L. Stomma, Pyrrusowa wiktoria, http://polityka.pl/historia/1531089, 1, wieden---niepotrzeb ne-zwyciestwo.r....

94 Ibidem: Czy mogła Turcja zdobyć Lwów? Zaprzeczyly temu zmagania chocimskie 9-11 września 1673 r. Czy mogła zdobyć Wiedeń? Zapewne. Utrzymać go jednak przez dhuższy czas - w czym historycy tureccy sa jeszcze bardziej kategoryczni - nie miała najmniejszych szans. Wojska Kara Mustafy zostaty pokonane przez zorganizowanq niemal ad hoc kontrofensywę chrześcijańskq. Cóż dopiero mówić, gdyby mobilizacja wojsk krzyża potrwała dłużej, przy jednoczesnym odcięciu tureckich linii zaopatrzenia, z którymi już i tak Kara Mustafa miat poważne kłopoty.

95 Ibidem: Rzeczpospolita posiadała wówczas znakomite służby dyplomatyczne (czytaj szpiegowskie) zwrócone przede wszystkim przeciwko Turcji, Rosji, Tatarom i Kozaczyźnie. Jest wiec nieprawdopodobne, by Jan III nie miat petnego rozeznania w sytuacji geopolitycznej [...] W tej mierze okresowe spustoszenie Wiednia, a co za tym idzie, osłabienie polityczne i finansowe Habsburgów powinno mu być na rękę. Dlaczego więc, mimo to zdecydowat się na kosztownq i ryzykowna pomoc austriackiej stolicy, i to wbrew interesom wielu państw ościennych? Historycy wysuwaja tutaj przynajmniej trzy hipotezy. Pierwsza- 
Na brak możliwości dłuższego, czy trwałego utrzymania przez Osmanów Wiednia, bądź nawet części Austrii, jak również nie traktowaniu wyprawy z $1683 \mathrm{r}$. przez nich jako dżihadu przeciwko chrześcijaństwu wskazał też wspomniany historyk turecki, Feroz Ahmad ${ }^{96}$. Ten problem jest nieco bardziej złożony. Rzeczywiście, sułtan Mehmed IV nie ogłosił wówczas jako kalif, ani wtedy, ani później oficjalnie dżihadu. Niemniej jednak, współcześni kronikarze osmańscy traktowali wyprawę przeciw Habsburgom w kategorii kolejnego wielkiego starcia muzułmanów z ,niewiernymi”. Także i sam Jan III jako gorliwie wierzący, w zachowanej korespondencji ze Stolicą Apostolską, akcentował religijne cele wyprawy i przyszłego starcia z armią Kara Mustafy ${ }^{97}$. W tym też celu, w intencji powodzenia wyprawy przebywał na Jasnej Górze, gdzie odbył m.in. uroczyste modły i otrzymał od przeora szablę hetmana Żółkiewskiego. Także podczas marszu swej armii odwiedził sanktuarium w Piekarach Śląskich, w Ołomuńcu, czy modlił się w austriackim Mariazell (to właśnie tamtejsza Matka Boska miała mu według niektórych zapewnić zwycięstwo $)^{98}$.

Czy zatem rzeczywiście Jan III Sobieski i współcześni mu władcy i politycy przeceniali siłę Imperium Osmańskiego i czy kompletnie mało realnym, z uwagi na postępującą słabość Turcji było rozciągnięcie przez nią wpływów na Górne Węgry (węg. Felvidék, obecną Słowację) w kierunku granic Rzeczypospolitej, a potem, w przypadku pokonania Habsburgów, zwrócenie się przeciw niej? Czy rzeczywiście polski król źle uczynił idąc im w sukurs?

Podobnie jak w innych przypadkach i tu odpowiedź nie jest prosta i wymaga nieco dłuższego komentarza. Wspomniany Silahdar Mehmed aga bardzo sugestywnie opisuje drogę armii Kara Mustafy przez zachodni obszar obecnych Węgier, najpierw pod Jawaryn, będący pierwotnie głównym celem kampanii, a potem zdobycie około

obawę przed zagrożeniem tureckim - możemy z góry odrzucić (sic!). Odparci pod Chocimiem Turcy dysponowali na Ukrainie tylko trzeciorzędnymi siłami. Po drugie, uwikłani w wojnę z Habsburgami, marzyć nawet nie mogli o przekroczeniu linii Karpat, co czyni zgoła bałamutnymi obliczanie kilometrów od Wiednia do Krakowa. Druga argumentacja ma charakter mistyczny, łaczy się z „,przedmurzem chrześcijaństwa” i misyjnymi koncepcjami polskiego władcy. Już jednak jego listy do Marysieńki budzq ugruntowane podejrzenia, iż tak mistycznym kawalerem Jan Sobieski nie byt, żeby przenosić krucjatowe mrzonki nad geopolityczny interes Ojczyzny. Świadczy o tym jego polityka międzynarodowa (choćby próby zbliżenia z Rosja), w której nijak nie widać religijnego pazura. Pozostaje możliwość trzecia - król wracajac opromieniony zwycięstwem nad Turkami liczył na umocnienie swej władzy, co pozwoliłoby mu na realizacje polityki majacej na celu - w tym większość dziejopisów jest zgodna - ujarzmienie i podporzqdkowanie Prus Wschodnich [wtedy jeszcze Książęcych - DW]. Jest to koncepcja, która wydawać by się mogła logiczna i spójna.

96 Por. Turecki historyk, op. cit.

97 Por. m.in. relacja nuncjusza papieskiego Opicio Pallaviciniego z Krakowa, 12 sierpnia 1683 roku z opisem błogosławieństwa ,wojny świętej” w katedrze wawelskiej; Odpis króla Jana III na breve papieża Innocentego XI, który prosił monarchę, aby ciągnął na pomoc oblężonemu przez Turków Wiedniowi; Jan do papieża Innocentego XI i kardynałów - sekretarza stanu Cibo i prokuratora Polski Barberiniego, z Gliwic, 24 sierpnia 1683, VVDV, s. 54 i n.

98 Por. Szlak Sobieskiego. Kraków-Wiedeń, http://szlak.sobieskiego.pl/rys-historyczny; Pielgrzym wśród pielgrzymów. Przewodnik Katolicki 32/2007, http://www.przewodnik.katolicki.pl/nr/ wiara_i_ko siol/pielgrzym_wsrod_pielgrzymow; 
100 zamków i umocnionych osad, tzw. palanek ${ }^{99}$. Kolejnym etapem było wkroczenie do obecnej Dolnej Austrii, zdobycie Hainburga, dotarcie pod Schwechat i wreszcie pojawienie się Turków pod samym Wiedniem i w jego okolicach ${ }^{100}$. Tylko na samym odcinku zachodnio-węgierskim, sukces osmański był niewątpliwe bardzo spektakularny i gdyby wielki wezyr tylko na tym poprzestał, byłby jednym z najbardziej skutecznych sułtańskich serdarów/seraskerów swoich czasów. Oprócz tego, nie można absolutnie zapomnieć o antyhabsburskich siłach Emeryka/Imre Thőkőlyego (tzw. krzyżowców - węg. kuruców), który chcąc zrzucić jarzmo austriackie, stał się przymusowym niejako lennikiem Turcji i opanował niemal całe Górne Węgry. To m.in. jego siły wsparły silny korpus osmański Abazy Kör Huseina paszy, beglerbeja Egeru i Tatarzy próbujący zdobyć Nitrę i Lewoczę, a który po dotkliwym spustoszeniu okolic obu tych miast ruszył na Preszburg (węg. Pozsony, obecna Bratysława) ${ }^{101}$. U schyłku sierpnia 1683 roku, książę Karol V Lotaryński (1643-1690), margrabia badeński Ludwik Wilhelm i Hieronim Lubomirski (generał w służbie habsburskiej) na czele swych oddziałów odnieśli spektakularne zwycięstwo nad wojskami wspomnianego paszy i Węgrami pod Bisambergiem k. Wiednia ${ }^{102}$.

Umocnienie się tam oddziałów Thőkolyego, ale przede wszystkim potencjalne zdobycze tureckie od linii środkowego Dunaju po Spisz zagrażałoby od północy nie tylko terenowi Austrii i samemu Wiedniowi, ale stanowiłoby dalsze rozszerzenie osmańskiej bazy wypadowej w kierunku północnym między Wagiem a Morawą, tj. aż do południowych granic Rzeczypospolitej. Zatem, spektakularne sukcesy armii

\footnotetext{
${ }^{99}$ SMaF, op. cit., s. 103-110.

100 Ibidem, s. 111-114.
}

101 O działaniach sił Karola Lotaryńskiego i margrabiego badeńskiego przeciw kurucom i posiłkującym ich korpusie Abazy Kör Huseina oraz rekonstrukcji źródłowej bitwy pod Preszburgiem, por. List Hieronima Augusta Lubomirskiego, marszałka nadwornego koronnego do Jana III z prośbą o przyspieszenie odsieczy Wiednia, [w:] VVDV, op. cit., s. 45; J. Wimmer, Wiedeń 1683, op. cit., s. 257-262; J. Stoye, op. cit., s. 188-102; S. Millar, op. cit., s. 56-58.

102 Pod Bisambergiem siły Karola lotaryńskiego liczyły około 12 tysięcy ludzi (tj. 12, 5 regimentów kirasjerskich, 5 dragońskich i około 2 tysiące Polaków. Natomiast siły osmańskie beglerbeja Egeru, Tatarzy i węgierscy kuruce również liczyli około 12 tysięcy, w tym 6 tysięcy Turków, 5 tysięcy Tatarów i około 1000 Węgrów. Bitwa pod Bisambergiem początkowo przyniosła sukces Osmanom, którzy częściowo rozbili polski pułk Hieronima Lubomirskiego (będący na służbie habsburskiej), jednak na oddziały Kör Huseina paszy spadło uderzenie w bok ich szyku pułku pancernych Remigiana M. Grocholskiego (także w służbie cesarskiej). Siły beglerbeja Egeru zostały rozbite, a on sam kilkakrotnie ranny. Klęska pierwszego rzutu osmańskiego spowodowała ucieczkę oddziałów jazdy i Tatarów, atakujących wówczas lewe skrzydło dowodzone przez margrabiego badeńskiego. Początkowo książę Karol obawiał się podstępu, widząc paniczny odwrót części sił tureckich obawiał się podstępu, jednak wydał H. Lubomirskiemu rozkaz pościgu. Oddziały polskie, dysponujące lepszą jazdą niż cesarskie, doścignęły Osmanów i Tatarów na brzegu Dunaju. Podczas starcia zginął Abaza Kör Husein pasza, poległo lub zostało wziętych do niewoli około 1000 Turków, zdobyto 25 sztandarów, wiele koni i innych łupów. Straty armii habsburskiej były natomiast stosunkowo niewielkie. Klęskę części swych wojsk oglądał sam Kara Mustafa i jego oddziały, co wywołało u nich znaczne przygnębienie, natomiast przyniosło radość oblężonej załodze Wiednia. Klęska Osmanów pod Bisambergiem i wcześniejsza porażka sił turecko-węgierskich pod Preszburgiem skłoniła Thőkőlyego i resztę rozbitych Turków i Tatarów do odwrotu za rzekę Wag. Por. J. Wimmer, Wiedeń 1683, op. cit., s. 265-267. 
habsburskiej księcia Karola V Lotaryńskiego przyniosły nie tylko pokonanie, często zupełnie niedostrzeganych lub tylko trochę wspomnianych przez badaczy sił Abazy Kőr Huseina paszy i kuruców pod Preszburgiem i pod Bisambergiem. To właśnie tych sił zabrakło już podczas bitwy pod Kahlenbergiem, gdzie mogły się przydać jako część obrony tureckiej wzgórza lub nawet wcześniej, by zatrzymać odsiecz chrześcijan. Owe dwie bitwy były także doskonałym przygotowaniem gruntu pod przyszłą wiktorię wiedeńską oraz procesu stopniowego odzyskiwania, czy zdobywania przez Austrię obszaru Węgier do schyłku lat 90. XVII wieku. Bez owych sukcesów za Dunajem, a zwłaszcza pod Bisambergiem i likwidacji perspektywy trwałej obecności garnizonów osmańskich na północy habsburskich Węgier, nadal istniałaby perspektywa przyjścia Kara Mustafie z odsieczą znacznych sił węgiersko -tureckich, czy nawet ewentualnego przeszkodzenia marszowi sił polskich zdążających pod Wiedeń. Zatem, bitwa wiedeńska nie była, jak się powszechnie uważa znaczącym, ale jednak dość lokalnym starciem, ale operacją militarną na znacznie szerszą skalę, rozciagającą się od ziem obecnej południowej Słowacji po habsburską stolicę.

Absolutnie nie umniejszając geniuszu militarnego Jana III i jego determinacji, by nie spóźnić się z odsieczą, a potem samej decyzji ulokowania wojsk na obszarze Lasu Wiedeńskiego, czy wreszcie roli w przebiegu samej bitwy, należy pamiętać o innym wybitnym wodzu koalicji. Tym człowiekiem był książę Karol Lotaryński, z którym zresztą polski król znalazł szybko porozumienie, a nawet i darzył go jako wybitnego wodza dużą sympatią, mimo tego, że wcześniej byli rywalami o polską koronę w 1674 roku $^{103}$.

Krytycy decyzji Jana III Sobieskiego, a zwłaszcza ci, którzy wytykają jej ,zbędność”, czy „działanie wbrew żywotnym interesom Rzeczypospolitej” we wsparciu Habsburgów, odsieczą, będących od dawna jej niechętnymi, zapominają o jednym, bardzo ważnym aspekcie kampanii wiedeńskiej. Ekspansja turecka, tak wcześniej, jak i w czasach oblężenia Wiednia miała wymiar istotnego zagrożenia cywilizacyjnego i kulturowego dla wszystkich, którzy znaleźli się w jej zasięgu.

Bezwzględność i okrucieństwa wojsk tureckich, które wyruszyły przeciwko habsburskim Węgrom, a potem pod Wiedeń jeszcze dziś, w drugiej dekadzie XXI wieku porażają czytelników kronik osmańskich swą dosłownością w opisie straszliwej furii zniszczenia dla samego zniszczenia i masowego zabijania tych żołnierzy i cywilnych mieszkańców, którzy mieli to nieszczęście znaleźć się na drodze Tatarów lub konnych oddziałów tureckich ${ }^{104}$. Czambuły tatarskie dotarły znacznie dalej, niż siły tureckie i swym zasięgiem objęły także znaczną część Dolnej Austrii i Styrii na zachód od Wiednia (obszar między Percholdsdorfem i Ebenfurthem, aż po Amstetten, Opponitz i Dürnstein), zwiększając znacznie skalę i zasięg wojny ${ }^{105}$.

Nieprawdopodobnemu wręcz zniszczeniu i złupieniu przez zagony osmańskie uległ zwłaszcza obszar między Hainburgiem, a Schwechat, a jego ofiarą stały się też

103 Por. O. Forst de Battaglia, op. cit., s. 198-199 i n.

104 Por. DHE, s. 217-218.

105 O działaniach Tatarów na obszarze Dolnej Austrii, por. J. Stoye, op. cit., s. 181-184. 
tamtejsze rezydencje i pałace cesarskie, oszczędzono jedynie ten, który był wzniesiony na wzór ozdobnego pawilonu sułtańskiego Sulejmana II (kiosk, tur. kősk) z 1529 roku, przez wzgląd na jego pamięć ${ }^{106}$. Zarówno u Silahdara Mehmeda agi, jak i innych autorów można znaleźć wiele fragmentów, które sumiennie opisują nieprawdopodobne wręcz przypadki bezmyślnego palenia (np. ogromnego składu drewna), niszczenia i łupienia wszystkiego, co tylko możliwe, zwłaszcza zamków i zameczków oraz miasteczek, masowego zagarniania w niewolę mieszkańców opanowanych ziem, gwałtów na kobietach i chłopcach, okrutnego ścinania i zabijania wziętych do niewoli ,jezzyków”, tj. jeńców ${ }^{107}$. Podobnych opisów jest tak wiele, że przekracza to ramy obecnego artykułu. Osmański dziejopis wyraża także zdumienie nad rozległym żywopłotem i finezją jego wykonania, wspaniałością ogrodów, zasobnością, urodzajnością plonów, czy bogactwem miast i miasteczek, a nawet zwykłych wsi Dolnej Austrii i Styrii, a zatem ich dystansem na korzyść chrześcijan pod względem cywilizacyjnym do podobnych, leżących w Imperium Osmańskim ${ }^{108}$. Nie mógł również wyjść ze zdumienia i podziwu, że: wojska muzutmańskie, ciagnac przez nie [tj. rozległe łany zbóż i winnice], tratowały [owe zasiewy], wypasaty na nich swe konie, podpalaty je, a mimo to większa ich część nadal kotysała się niby morze $e^{109}$.

Opublikowane listy Hieronima Lubomirskiego, a także księcia Karola Lotaryńskiego dość dobrze oddają grozę ówczesnej sytuacji ${ }^{110}$. Stąd też decyzja polskiego króla o pomocy dla oblężonej stolicy Austrii była jak najbardziej uzasadniona. Ewentualny sukces turecki i sprzymierzonych z Osmanami kuruców Thőkőlyego na pewno oddałby pod panowanie osmańskie znaczną część, jeśli nie całość habsburskich Węgier. A stamtąd ta ogromna fala zniszczenia i rzezi, która dotknęła obszar pogranicza węgiersko-austriackiego mogłaby przenieść się dalej na północ i wlać się następnie w granice Rzeczypospolitej.

Broniąc Habsburgów i ich stolicy, Sobieski był jednym z tych wielkich polityków i władców europejskich, który nie dopuścił do wzmocnienia (nawet przejściowego) potęgi osmańskiej. Nikt, albo prawie nikt nie mógł zagwarantować, że ekspansja turecka nie skieruje się znów przeciw Rzeczypospolitej, po jakiś kolejny elajet, czego wyczerpany długoletnimi wojnami kraj, mógłby w końcu nie wytrzymać. Zatem polski król angażując się $\mathrm{w}$ odsiecz Wiednia, wraz z wojskami koalicji chrześcijańskiej, być może zapobiegł osmańskiemu sukcesowi, którego jednym z następstw byłoby utrzymanie na już dłużej całości Węgier, a potem kolejna, straszliwie niszcząca wyprawa na „Lechistan”.

Czy potrzebne były dalsze wielkie polskie zdobycze i zwycięstwa kosztem osmańskim na Węgrzech, tj. Parkany (dziś słowackie Šturovo), Ostrzyhom (węg. Esztergom, niem. Gran) i przygotowywanie gruntu pod przyszłe panowanie habsburskie nad ca-

\footnotetext{
$106 \mathrm{SMaF}$, op. cit., s. 112-114.

107 Ibidem, s. 113.

108 Ibidem, s. 114.

109 Ibidem.

110 Por. VVDV, op. cit., s. 45 i n.
} 
łością ziem Korony św. Stefana po 1699 roku? To pytanie jest dziś jedynie podstawą pod rozważania o charakterze czysto teoretycznym. Natomiast marsz pod Wiedeń oznaczał wtedy przynajmniej czasowe odsunięcie „niebezpieczeństwa tureckiego”, także i wobec Rzeczypospolitej. Nikt też nie przewidział skali sukcesu pod Wiedniem i jego dalszych następstw. Wcale nie było bowiem nigdzie powiedziane, że nie nastąpi powrót do sytuacji jaka zaistniała w 1529 roku, tj. Wiedeń został wprawdzie ocalony, ale panowanie osmańskie tylko trochę się cofnęło na pozycje wyjściowe, tracąc większość nabytków terytorialnych z kampanii 1683 roku, tj. zwłaszcza habsburskie Węgry. Nadal jednak zagrożenie istniało i gdyby nie dalsze zwycięskie postępy armii Habsburgów w latach 1684-1687/97, kto wie, czy Turcja nie odbudowałaby swej potęgi nadwątlonej klęskami i znów nie przeszła do kontrofensywy na Węgrzech, lub zwróciła się przeciw coraz słabszej Rzeczypospolitej...

Późniejsze i współczesne nam opinie na temat „wsparcia dla przyszłego zaborcy" w odniesieniu do realiów roku 1683 są zgoła niepoważne, bo nikt nie mógł przewidzieć, jak rozwinie się sytuacja nawet w ciągu najbliższych kilku, kilkunastu lat, nie mówiąc już o w drugiej połowie XVIII wieku. Nawet magnateria i część szlachty niekiedy bardzo niechętna Sobieskiemu nie mogła przewidzieć, jak dalece posunie się naprzód proces osłabienia Rzeczypospolitej i wzrostu siły takich sąsiadów jak nowopowstałe w 1701 roku Królestwo Prus, nie mówiąc już o Wielkim Księstwie Moskiewskim, przyszłym Imperium Rosyjskim. Krytycy Sobieskiego przypominają, zatem, nieco tych starych marszałków, generałów i weteranów wojskowych, którzy znakomicie by wiedzieli lub wiedzą, jak wygrać wielką wojnę...już niestety dawno minioną.

Zdają się też owi krytycy nie rozumieć prostego faktu, że kolejny znaczący najazd tatarski, czy turecki, a zwłaszcza wyprawa osmańska z 1683 roku nie były tylko teoretyczną abstrakcją, lecz niszczącym wszystko żywiołem, którego skutki dla obszaru Europy Środkowej mogłyby być naprawdę tragiczne w razie powodzenia. Tak więc, sytuacja w drugiej połowie tego roku wcale nie przynosiła optymistycznych wniosków. W tym czasie bowiem, potęga militarna Turcji była faktem, o czym pisze m.in. Jan Reychman i wbrew późniejszym i nawet obecnym tezom o jej „kryzysie”, czy „słabości”, trzeba było jeszcze kilkunastu lat ciężkich i wyczerpujących wojen, by Imperium Osmańskie od 1699 roku zaczęło przechodzić do defensywy ${ }^{111}$.

Sądy na temat faktycznej słabości tureckiej w czasach kampanii wiedeńskiej i przyszłego, „nieuchronnego" upadku panowania tureckiego, są być może skutkiem bardzo modnego dziś prezentyzmu, który brzmi w swych tezach i sądach pozornie bardzo atrakcyjnie, ale dla części historyków stanowi zbyt daleko idące naginanie faktów, nadinterpretację, czy nawet nie uwzględnienie ówczesnych realiów, nie mówiąc już niekiedy o braku gruntownej wiedzy na temat tamtych wydarzeń. Obecnie ferowany jest szczególnie chętnie przez różnych zwolenników „laickości” i ,świeckiego państwa", np. we Francji, Niemczech, ale także i w Polsce trend niechętny religii, czy szczególnie chrześcijaństwu i katolicyzmowi. Gloryfikacja zwycięstwa wie-

111 Por. J. Reychman, Historia Turcji, Wrocław 1973, s. 110-111, 148. 
deńskiego, a już zwłaszcza jego religijnych aspektów jest niekiedy traktowana przez środowiska lewicowe i liberalne jako jeszcze jeden dowód na „klerykalizm”, głęboko zakorzenioną , islamofobię” u niektórych wrogich „multikulturalizmowi” i „postępowi” konserwatywnych i ,zacofanych” mieszkańców Europy Środkowej i Środkowo-Wschodniej. Nie pojmują oni bowiem, (zdaniem „postępowców”), czy nie chcą pojać swym ,prostackim” i skrajnie uproszczonym widzeniem świata, ani dobrodziejstw politycznej poprawności, zasad „tolerancji”, ani tym bardziej „logiki postępu”, czy „kierunku w jakim zmierza współczesny świat”.

Wydaje się, że ostatnio, tj. we wrześniu 2014 roku, najtrafniej podsumował celowość polskiego udziału pod Wiedniem i jednocześnie różne błędne, bądź mało zasadne, dawniejsze i współczesne oceny na temat pomocy Sobieskiego dla Habsburgów, wspomniany wcześniej Radosław Sikora w jednym ze swych artykułów ${ }^{112}$. Tenże badacz dziejów husarii pisze co następuje:

Do niedawna wydawało się, że żyjemy w stabilnym świecie, którego najbliższą przyszłość stosunkowo łatwo można było przewidzieć. Tymczasem ostatnimi czasy historia uległa przyspieszeniu. Rozpalająca się wojna na Ukrainie wieszczy zmiany w układzie geopolitycznym tej części Europy. Konia z rzędem temu, kto dziś potrafi przewiedzieć, jak będzie wyglądała sytuacja w naszym regionie za rok. A jak będzie wyglądała za lat dziesięć? A za kilkadziesiąt lat? Nikt nie wie ${ }^{113}$.

Do pierwszego rozbioru Polski doszło w 1772 roku, czyli dokładnie 89 lat po odsieczy wiedeńskiej. Jeśli nawet komukolwiek w najgorszych snach, przyszedł by do głowy w roku 1683, to podejmowanie decyzji na tej podstawie było by czynem szaleńca. To mniej więcej tak, jak gdyby ktoś chciał prewencyjnie napaść na Czechy, bo ma niejasne przeczucie, że ten kraj za niemal dziewięć dekad upomni się o Śląsk, który był kiedyś jego częścią. Jan III Sobieski wiedział, że nawet najpotężniejszy kraj nie powinien być otoczony tylko przez wrogów. Rzeczpospolita w jego czasach nie była już u szczytu potęgi. Sąsiadowała z państwami, które nawet w pojedynkę mogły sprawić jej wiele kłopotów. A co dopiero, gdyby zjednoczyły się przeciw niej? Koniecznością było szukanie sojuszników tam, gdzie możliwe. Państwo Habsburgów było najlepszym z możliwych kandydatów. Po pierwsze, nie toczyliśmy z nim wojen od niemal stulecia. A właściwie nawet dłużej, gdyby interwencję arcyksięcia Maksymiliana III Habsburga w Polsce pod koniec 1587 roku, trudno uznać za wojnę z państwem. W XVII wieku oba nasze kraje militarnie sobie pomagały. My wsparliśmy cesarza w czasie wojny trzydziestoletniej. Cesarz pomógł nam w dobie ,potopu”. Ponadto państwo Habsburgów, mimo iż rządzone przez nielubianych przez nas Niemców, było jedynym krajem katolickim, z którym sąsiadowaliśmy. W owych czasach było to bardzo ważne. Wspólne wartości tworzyły solidną bazę porozumienia. Sojusz z tym państwem był, więc, sojuszem naturalnym, a nie egzotycznym, który mógł się rozpaść za lada powiewem wiatru historii. To, co w 1683 roku uczynił Sobieski było rzeczą nie tylko logiczną, ale i najrozsądniejszą w tamtych okolicznościach. On i ówczesne pokolenie Polaków zrobili to, co należy. A że kilkadziesiąt lat później doszło do rozbiorów Polski? Winić trzeba za to nie jego, ale ludzi żyjących w ostatnich dekadach XVIII wieku"114.

To chyba jest najlepsze podsumowanie całej dyskusji.

112 Por. R. Sikora, Bitwa pod Wiedniem odmieniła bieg historii, http://historia.wp.pl/title, Bitwapod-Wiedniem-odmienila-bieg-historii,wid,16877159,...

113 Ibidem.

114 Ibidem. 


\section{ROLA MEDIÓW I PROGRAMÓW NAUCZANIA \\ W KREACJI SĄDÓW I MITÓW NA TEMAT BITWY POD WIEDNIEM.}

Przy okazji 300-lecia bitwy pod Wiedniem, TVP nakręciła w 1983 roku, bardzo dobry (jak na tamte czasy) fabularyzowany dokument „Na odsiecz Wiedniowi”, w reżyserii Lucyny Smolińskiej i Mieczysława Sroki. W filmie wystąpili wybitni (nieżyjący już dziś niekiedy) polscy aktorzy ${ }^{115}$. Obraz został wyprodukowany zapewne pod wpływem popularnej niegdyś i bardzo dobrej merytorycznie, dokumentalnej serii francuskiej „Les grandes batailles de histoire” (Wielkie bitwy historii), emitowanej w Polsce od połowy lat 70. XX w. Do dziś jeszcze scenariusz tego filmu i wartość historyczna broni się bardzo dobrze, a jego walory edukacyjne, mimo pewnych archaizmów technicznych (co jest nieuchronne z uwagi na stały postęp w tej dziedzinie) są nadal wysokie. Przede wszystkim pozbawione są często niemądrych, wziętych nie wiadomo skąd wątków i zdarzeń w scenariuszu, nie mających odniesienia do rzeczywistych wydarzeń. Wynika to również z postępującej ignorancji i kulturowego „,równania w dół”, tak samych realizatorów, jak i do chęci zrównania się z coraz niższym poziomem intelektu tzw. masowego widza i osiągnięcia wysokich wskaźników „oglądalności”.

Te ostatnie, to dosyć widoczne wady wspomnianego wyżej filmu Renzo Martinellego, z czego zdaje sobie sprawę nawet jego sam jego producent. W wywiadzie stara się przekonać, że nie jest to film historyczny, a jedynie ,przygodowy, w konwencji fantasy, nakierowany na wysoką oglądalność"116. W innym miejscu mówi on o filmie przygodowym, który ma odnieść się do współczesnej sytuacji Europy”, a także „opowiedzieć o bitwie, która ocaliła Europę przed islamizacją"117. Dziś, jego zdaniem, film spełnia funkcję nowoczesnej „Biblii ubogich” (Biblia pauperorum). To dowodzi jednak, że rozpowszechniana dziś opinia o społeczeństwie XXI wieku, jako „społeczeństwie wiedzy" jest ferowana mocno na wyrost.

Obraz Martinellego wszędzie na świecie, także i w Polsce spotkał się z ogromną falą niezadowolenia. Zawodowi krytycy lub fani kina określili go ,najgorszym filmem 2012 roku”. Wytykali reżyserowi ewidentną słabość fabuły, dialogów, widoczne potknięcia techniczne, daleko idący mistycyzm, przypisanie zbyt dużej roli bratu Marco d'Aviano, czy natrętny dydaktyzm katolicki i zbytni krytycyzm wobec isla-

115 Por. Na odsiecz Wiedniowi, http://www.youtube.com/watch?v=f8RLCU7EwBY. W filmie wystąpili m.in. Jerzy Bińczycki (jako król Jan III Sobieski), Anna Dymna (Maria Kazimiera d'ArquienMarysieńka), Jerzy Trela (Kara Mustafa), Franciszek Pieczka (Ibrahim pasza), Karol Strasburger (Karol V Lotaryński), chan Murad Girej (Leonard Andrzejewski). Jako materiał ilustracyjny wykorzystano m.in. fragmenty takich filmów fabularnych jak „Pan Wołodyjowski”, „Potop”, czy „Ojciec Królowej”.

116 Por. Bitwa pod Wiedniem nie jest filmem przygodowym - WPROST, http://www.wprost.pl/ ar/35164/Bitwa-pod-Wiedniem-nie-jest-filmem-historycznym/.

117 Por. Producent: „Bitwa pod Wiedniem” to film przygodowy, a nie historyczny, http://dzieje.pl/ film/ producent-bitwa-pod-wiedniem-film-przygodowy-nie-historyczny. 
mu ${ }^{118}$. Przykładowo, Joanna Ostrowska na łamach portalu Interia.pl nie szczędziła słów krytyki za jego „natrętnie katolicką” i ,,antymuzułmańską wymowę”, brak politycznej poprawności, czy gloryfikację postaci Polaka-katolika" ${ }^{119}$. Jedynie nieliczne głosy, podkreślające właśnie zwrócenie uwagi na współczesne zagrożenie Europy ze strony islamu miały charakter pozytywnej oceny ${ }^{120}$. W każdym razie, rzeczony film dokumentalny L. Smolińskiej i M. Sroki, mimo lat, które upłynęły od jego powstania, swym poziomem mocno jak się okazuje, odstaje dziś na korzyść od podobnych, współczesnych produkcji filmowych. Podobnie jak i odstaje od „nowoczesnych metod nauczania", niekiedy dość miałkich i płytkich intelektualnie, a stosowanych powszechnie przy realizacji obecnych lekcji szkolnych, których tematem jest Jan III Sobieski i jego wyprawa pod Wiedeń, o czym niżej.

W następnych latach wątek bitwy wiedeńskiej i dyskusja o jej roli, także udziału w niej wojsk króla Jana i jego politycznej celowości pojawiała się niejednokrotnie w różnym kontekście. Przypomnienie o oblężeniu Wiednia i wiktorii 1683 roku pojawiło się zwłaszcza w kontekście wydarzeń z 11 września 2001, rozpatrywanych jako element ,zderzenia cywilizacji” i odwiecznej walki chrześcijaństwa, czy cywilizacji zachodniej z islamem. Kolejnym impulsem było wydanie przez znaną dziennikarkę włoską, Orianę Fallaci (zm. 2006) jej kilku książek w których wskazywała na problem tzw. „Eurabii” i stale rosnącej obecności fizycznej i kulturowej muzułmanów w Europie, które jej zdaniem stanowią ogromne niebezpieczeństwo cywilizacyjne dla kontynentu ${ }^{121}$.

W roku 2006 światowe media, a zwłaszcza polskie obiegła wiadomość o projekcie filmowym dotyczącym nakręcenia obrazu o bitwie pod Wiedniem, za astrono-

$118 \mathrm{Na}$ temat negatywnych ocen filmu R. Martinellego por. m.in. „Corriere della sera”: kontrowersje wokół filmu „Bitwa pod Wiedniem”, http://wiadomosci.wp.pl/drukuj/html?wid+15159409; Z. Pietrasik, Blamaż pod Wiedniem, http://www.polityka.pl/tygodnikpolityka/kultura/film/1531039,1recenzja-filmu -bitwa...; D. Kuźma, [DVD] „Bitwa pod Wiedniem”: vanitas vanitatum..., http://film.onet.pl/recen zje/dvd-bitwa-pod-wiedniem-vanitas-vanitatum/hb114; R. Błaszczak, „Bitwa pod Wiedniem”, Renzo Martinelli, http://kafeteria.pl/ kultura / bitwa-pod-wiedniem-renzo-martinelli-a_5364; S. Adamkiewicz, Bitwa pod Wiedniem-historyczna wtopa roku?, http;//histmag.org/Bitwa-pod-Wiedniem-historycznawtopa-roku-7124; Bitwa pod Wiedniem jest najgorszym filmem tego roku, http://www.filmweb.pl/film/ Bitwa+pod+Wiedniem-2012-617280/discussion/BITWA....

119 Por. J. Ostrowska,, Bitwa pod Wiedniem”: nawet wilkołaki ratują chrześcijaństwo, http://film.in teria.pl/ recenzje/ news/ bitwa-pod-wiedniem-nawet-wilkolaki-ratuja-chrze...

120 Por. K. Kratiuk, Pozytywnie o „Bitwie pod Wiedniem”, http://www.pch24.pl/pozytywnie-obitwie-pod-wiedniem, 6712,i.html?print=1.

${ }^{121} \mathrm{O}$ poglądach Oriany Fallaci na temat rosnącej obecności muzułmanów w Europie i niebezpieczeństw z tym związanych, a zwłaszcza zagrożeń cywilizacyjno-kulturowych, t.zw. ,polityki brzucha” oznaczającej istotne zmiany w demografii znacznej części kontynentu na korzyść wyznawców islamu i procesu starzenia się „rdzennych Europejczyków”, a zawartych w jej książkach wydanych na przełomie XX i XXI w. (,Wściekłość i duma”, „Siła rozumu” i „Wywiad z samq sobq. Apokalipsa”, także tłumaczonych na polski w latach 2003-2004), problemie „Eurabii”, por. w ostatnich latach m.in. D. Wybranowski, Mit wielkiego zwycięstwa pod Poitiers (732/733) jako ocalenia Zachodu przed podbojem muzułmańskim a współczesny problem „Eurabii” - „Europy w cieniu Półksiężyca” [w:] Mity historyczno-polityczne wyobrażenia zbiorowe - polityka historyczna. Studia i materiały, red. E. Ponczek, A. Sepkowski, Toruń 2012, t. II, s. 155-156, 161-162. 
miczną wręcz sumę (jak na realia filmu polskiego) 120 milionów złotych, które wyłożyć miał m.in. polski biznesmen, Wojciech Białek. Ten projekt nosił tytuł roboczy Victoria, a jedną z głównych ról miał zagrać jeden z najwybitniejszych aktorów i reżyserów kina światowego - Mel Gibson, który miałby też zająć się reżyserią całości ${ }^{122}$. Scenariusz filmowy pod tą samą nazwą napisał Cezary Harasimowicz, a całość została wydana w formie książkowej w 2007 roku, tam także w zamieszczonej przedmowie wypowiedział się W. Białek, przyszły (niedoszły) sponsor tego filmu na temat jego wrażeń z obchodów polsko-austriackich 300-lecia bitwy w Wiedniu i konieczności opowiedzenia tej historii językiem filmowym na nowo. Nawiązał także do jego zdaniem istotnego związku pomiędzy zwycięstwem z 1683 roku, a zniszczeniem wież World Trade Center przez islamskich terrorystów z Al-Kaidy w 2001 roku ${ }^{123}$.

Trzeba jednak przyznać, że historyzm i realizm tego scenariusza i książki C. Harasimowicza i tak jest jednak daleko lepszy, niż przyszły obraz filmowy R. Martinellego. Autor wprowadził też wątek pięknej chrześcijańskiej branki, Blanki Lorentz (będącej typem ówczesnej „kobiety wyzwolonej” i dominującej, zgodnej z politycznie poprawną obecnie wykładnią i współczesną modą filmowa), w której zakochał się sam wielki wezyr ${ }^{124}$. Możliwe także, że C. Harasimowicz, chciał napisać scenariusz do typowego filmu przygodowego, $\mathrm{z}$,absolutnie niezbędnym” obecnie, a rozbudowanym wątkiem romansowym, jedynie „opartym na motywach” bitwy wiedeńskiej. Zaletą tej książki są odniesienia do rzeczywistych wydarzeń i dobrze napisane sceny batalistyczne. W przypadku jednak wielu innych twórców wydaje się jednak, że zbyt często ponosi ich wena twórcza, a zapominają, że rzeczywiste wydarzenia są same w sobie ciekawe i stanowią gotowy materiał na scenariusz, aniżeli szukanie jakichś nieprawdopodobnych pomysłów i wątków, często kompletnie sztucznie wymyślonych, a czasem będących dowodem na niewielkie talenty scenarzystów lub reżyserów, którzy chcą błysnąć własną inwencją (której czasem niestety brak) i np. wsparciem ,żelaznych" zasad politycznej poprawności w obsadzie.

Natomiast na kartach wspomnianej książki C. Harasimowicza, Kara Mustafa jest postacią iście demoniczna, która ma również przemożny wpływ na samego sultana Mehmeda IV. Otwarcie mówi on władcy osmańskiemu nie tylko o zamiarze zdobycia Wiednia, ale i w niedalekiej przyszłości i samego Rzymu (ostrze naszego miecza musi ściać Złote Jabłko), a nawet pokazowego ścięcia papieża [Innocentego XI] jako duchowego przywódcy ,niewiernych”. Podobny sąd wyrażony w książce wydanej w dużym nakładzie może, choć nie musi ugruntować kolejny mit. W rzeczywistości, sułtan dowiedział się o zmianie kierunku wyprawy dopiero w jej trakcie, a decyzja Kara Mustafy była w istocie samowolą, za którą w obliczu spektakularnego fiaska potem przyszło mu zapłacić własnym życiem w Belgradzie. Wezyr opowiada sułtanowi Mehmedowi także o tym, że bazylika Piotrowa w przyszłości postuży

122 Por. Mel Gibson zagra Jana III Sobieskiego w polskim filmie?, http://www.filmweb.pl/news/MelGibson-zagra-Jana-III-Sobieskiego-w-polskim...

123 Por. C. Harasimowicz, Victoria. Venimus, vidimus, Deus vicit”, Warszawa 2007, s. 5-9.

124 Ibidem, s. 150 i n., 229-230. 
jako stajnie dla jego koni ${ }^{125}$. Chyba jedną z ciekawszych postaci jest tu Polak, występujący w książce jako „Franz Kultz”, w rzeczywistości mający swój pierwowzór we Franciszku Kulczyckim, zaufanym emisariuszu Sobieskiego, człowiekowi znającemu turecki i tatarski (co pozwalało mu w przebraniu przechodzić przez osmańskie linie oblężenia), a potem miłośnikowi i propagatorowi picia zdobytej w obozie osmańskim kawy w Wiedniu ${ }^{126}$. Było to także możliwe, dzięki wątpliwej lojalności względem Osmanów sił lenników chrześcijańskich - Wołochów i innych, którzy wspierali swych tureckich panów na tym odcinku oblężenia tylko z konieczności ${ }^{127}$.

Pomysł na podobny film nie doczekał się ani wówczas, ani potem realizacji, a tym bardziej uczestnictwa w nim samego Mela Gibsona. Okazało się jednak niebawem w ostatnich latach, że sztuka filmowa zostanie wystawiona na ciężką próbę, a umiejętność nakręcenia dobrego, a zarazem wiarygodnego i logicznie spójnego filmu historycznego, którego tematem byłaby odsiecz Wiednia w 1683 roku jest kompletnie „nie do zrobienia" dla współczesnych twórców, tak scenarzystów, jak i reżyserów, a powodem nie są kwestie finansowe (bo nader chętnie niefrasobliwie marnowane są bardzo znaczące pieniądze na filmy słabe, treściowo i artystycznie kompletnie chybione, za to „postępowe w treści”). Tu także przyczyną jest niewielka wiedza, zupełna ignorancja, czy niechęć do słuchania głosów konsultantów, którzy być może są w stanie czasem przekonać producenta i twórców do takich elementów jak strój, czy uzbrojenie z epoki. Natomiast już nie do historyczności fabuły i jej związku z rzeczywistością, czy sposobu myślenia i mowy (być może ich zdaniem, „zbyt nudnej” „niezrozumiałej dla współczesnych młodych ludzi” i „trudnej w odbiorze”). W obecnych czasach takie wybitne obrazy i klasyka kina wojennego jak „The Longest Day” (Najdłuższy dzień), „A Bridge too Far” (O jeden most za daleko), czy „Tora, Tora, Tora!” chyba miałyby obecnie małe szanse na powstanie.

Dziś, zdaniem filmowców, widzowi należy wszystko „uwspółcześnić”, lub „przybliżyć współczesnemu widzowi” (tj. masowemu), tak by jedynie w taki sposób uświadomić mu ,przeszłość”, lub jakąs nieokreśloną „,dawność” co jest klasyczną intelektualną drogą donikąd, bo ma ukazać świat niemal taki sam jak dziś, tylko ludzi inaczej ubranych. Jakakolwiek ,archaizacja” języka używanego przez postacie filmowe, wobec dzisiejszego ubóstwa językowego, jakie niesie współczesna edukacja, czy ukazanie świata zbyt odmiennego od znanego, także są tu głęboko „niewskazane”, bo tylko niepotrzebnie tworzą brak zrozumienia i tzw. dysonans poznawczy, zwłaszcza u młodych ludzi.

Niewątpliwie jednak różne dyskusje i kontrowersje, (a przy okazji także asumpt do kreacji nowych mitów ,wiedeńskich”) uległy wzmożeniu zwłaszcza w drugiej dekadzie XXI wieku, gdy pojawiła się sprawa przygotowań, a następnie premiery wspomnianego filmu Renzo Martinellego. Przeglądając plany metodyczne lekcji historii w szkołach różnych szczebli, trzeba niestety zaznaczyć, ze obecni metodycy i na-

125 Ibidem, s. 17- 21.

126 Ibidem, s. 93 i n., 130-132. O tej postaci szerzej por. m.in. J. Wimmer, op. cit., s. 252-253.

127 Por. O. Forst de Battaglia, op. cit., s. 213. 
uczyciele wykorzystują, niestety, wspomniany film włoskiego reżysera, jako ,zalecaną" pomoc dydaktyczną ${ }^{128}$. W sieci są także dostępne różne plany i konspekty lekcyjne, czy poradniki metodyczne w tej mierze ${ }^{129}$. Są one dosyć zróżnicowanej jakości i zawartości merytorycznej. Nie umniejszając chwalebnych zamiarów, czy intencji bardziej skutecznego odwołania się do wyobraźni i dotychczasowej wiedzy uczniów podczas lekcji, rzeczony film, ale też prezentowane przez niektórych autorów/autorki w zamieszczonych w sieci konspektach, ćwiczenia dają wiedzę nader powierzchowną, płytką, a niekiedy nawet i żadną, tak o samej bitwie pod Wiedniem, jak i o epoce, w której się ona rozegrała. Jest też oczywiste, że podobne obrazy służą utrwalaniu

128 Podobne metody dydaktyczne i film Renzo Martinellego jako kolejna pomoc w edukacji dla uczniów i materiał dla przeprowadzenia zajęć lekcyjnych prezentuje zbiór najprawdopodobniej mający związek z twórcami rzeczonego obrazu, jako sponsorami. Por. Bitwa pod Wiedniem. Materiały dla szkoły podstawowej, gimnazjum i szkół ponadgimnazjalnych, Wydawnictwo Nowa Era [2012?]. Materiał jedynie trochę i w detalach jest zróżnicowany pod względem szczebla nauczania. Podstawowym źródłem wiedzy dla uczniów jest podręcznik szkolny „Śladami przeszłości 2" i strony od 246-253. Część wstępna w/w zbiorku to bardzo krótka charakterystyka kilku głównych postaci z filmu (Jan III, Kara Mustafa, Karol Lotaryński, Eleonora Lotaryńska, Marco d'Aviano, cesarz Leopold Habsburg, wraz z podaniem nazwisk grających ich aktorów (w kolejności: Jerzy Skolimowski, Enrico Lo Verso, Antonio Cupo, Alicja Bachleda-Curuś, F. Murray Abraham, Piotr Adamczyk). Stosunkowo niewielki, czy bardzo skrótowy opis wydarzeń historycznych zamieściła dr Anna Ziemleńska. Poza tym, uczniowie mogą zapoznać się z informacją na temat husarii (z ilustracjami), charakterystyką pochodzenia rodu Sobieskich, samego Jana III jako „króla-Sarmaty” (tu także niewielka charakterystyka tego, czym był sarmatyzm pod względem stroju, kultury, ale też i zjawiska ,anarchii szlacheckiej”). W zależności od szczebla i rodzaju szkoły, uczniom przydzielane są krótkie zadania w rodzaju sporządzenia drzewka decyzyjnego, uzupełnień tekstów, itp. Pomocą dydaktyczną jest także bardzo niewielki objętościowo fragment opisu czasów bliskich bitwie pod Wiedniem, autorstwa zmarłego prof. Zdzisława Żygulskiego jun., pochodzący z zeszytu jego autorstwa, dotyczącego odsieczy Wiednia, wydawanego w ramach znanej przed laty serii popularnonaukowej „Dzieje Narodu i Państwa Polskiego”, t. II, nr 32, Kraków 1994. W omawianym zbiorku „Bitwa pod Wiedniem. Materiały..." znalazł się także dość niewielkich rozmiarów wywiad z reżyserem filmu, R. Martinellim, który jednak nie wnosi zbyt wiele do poznania uwarunkowań historycznych wyprawy wiedeńskiej, a raczej jest tłumaczeniem „śmiałej” i „nowoczesnej” wizji jego filmu.

129 Tu przykładem może być konspekt lekcji do przeprowadzenia w klasie VI szkoły podstawowej. Jego autorką jest Anna Kołodziejczak z Centralnego Gabinetu Edukacji Filmowej. W części wstępnej zostały sprecyzowane cele lekcji, polegające na określeniu dat zdobycia Kamieńca (1672), bitwy pod Chocimiem (1673) i bitwy pod Wiedniem (1683). Uczeń ma je określić na taśmie chronologicznej, a oprócz tego zdefiniować pojęcia: „oblężenie”, ,odsiecz”, ,sułtan”, „husaria”, ,,janczar”, „,wielki wezyr”, „islam”. Ma także krótko omówić przyczyny wojen polsko-tureckich za Sobieskiego, wskazać na mapie tereny gdzie te wojny się toczyły i kluczowe miejsca z nimi związane: Kamieniec, Chocim i Wiedeń. Dalszym etapem lekcji jest przyporządkowanie w krótkim teście Kara Mustafy, Leopolda Habsburga, Marka z Aviano, Jana III Sobieskiego, Eleonory Lotaryńskiej i sułtana Mehmeda IV do właściwego opisu charakterystycznego dla tej postaci. To zadanie jest przeznaczone nawet aż do pracy zespołowej, a nie indywidualnej (sic!), tj. dopiero połączone siły kilku uczniów mogą dać odpowiedź, a raczej nie sam pojedynczy uczeń. W części końcowej każdy z uczniów otrzymuje krótki, bo kilkuzdaniowy tekst do uzupełnienia, który jest następnie oceniany przez nauczyciela. Uczeń dostaje również do wykonania pracę domową, w której ma napisać krótki list Sobieskiego do królowej Marysieńki po zakończeniu bitwy. Mają się w nim znaleźć takie elementy jak: data i miejsce wydarzenia, jego krótki opis i osoby biorące w nim udział. Por. 12 września 1683 roku - wiktoria wiedeńska, http://edukacjafilmowa.pl/materialy-edukacyjne/scenariusze-zajec/item/70-bitw... Możliwe, że pomysłodawcy tego zadania nie wiedzą, że podobne listy napisał sam Jan III do swej żony, które potem nawet zostały wydane drukiem... 
w świadomości masowej mitów, półprawd, a nawet ewidentnych zmyśleń scenarzystów i reżysera.

Na pewno znacznie lepszym pod względem merytorycznym i wierności wydarzeniom historycznym byłby użyty tu, jako pomoc, wspomniany wyżej film dokumentalny z 1983, Mieczysława Sroki i Lucyny Smolińskiej, obecny na portalu YouTube. Pytanie jednak, czy dla współczesnego ucznia, będącego produktem Facebooka, Twittera i innych portali społecznościowych, członka „społeczeństwa sieci” (internetowej), posiadacza supernowoczesnego smartfona, iphone'a, tabletu, itp., podobny film nie byłby „zbyt nudny”, „trudny” i mało zrozumiały pod względem używanego języka i terminologii?! Kto wie, czy podobne problemy nie zaistniałyby również i dla obecnej generacji młodych nauczycieli, będących przecież także częściowo produktem pseudoreform oświatowych ostatnich dekad i fatalnego systemu studiów. Zapewne tylko pewna część z nich wie (lub nie) o istnieniu podobnego filmu ,aż sprzed 30 lat", podobnie jak i znaczącej literatury fachowej problemu, zwłaszcza tej nieco starszej... Podkreślić należy natomiast, że zwycięstwo pod Wiedniem i postać Jana III Sobieskiego, jako jednego z głównych jego twórców, stała się podstawą do projektu ustawy Sejmu RP, która miała uczcić w 2013 roku 330 rocznicę tych wydarzeń $^{130}$.

\section{ZAKOŃCZENIE}

Podsumowując powyższe ustalenia stwierdzić należy:

- Początkowo głównym celem wyprawy armii Kara Mustafy były jedynie dwie twierdze i miasta w habsburskiej części Węgier: Jawaryn (Győr) i Komarno (Komárom) oraz wydatne wsparcie sił antyhabsburskich kuruców Emeryka Thőkőlyego operujących na terenie Górnych Węgier (obecnej Słowacji). Zgromadzone siły w wysokości ponad 100 tysięcy wojsk różnych formacji w zupełności się do tego nadawały, jako realizacja tego etapu działań, czy fazy podboju.

- Decyzja o marszu na Wiedeń była efektem jednostkowego rozkazu wielkiego wezyra, początkowo bez wiedzy i pozwolenia sułtana Mehmeda IV, który przyjął postawę wyczekującą wobec dalszego rozwoju wypadków. Władca ten miał prosty wybór - w razie ewentualnego sukcesu Kara Mustafy musiałby go nagrodzić, mimo zmiany przez niego decyzji o głównych celach wyprawy. Jednak w razie niepowodzenia miał doskonały pretekst do tego, by definitywnie pozbyć się zbyt ambitnego i pysznego dostojnika. Osmański serdar ponosi też całkowitą odpowiedzialność za znaczące rozszerzenie działań armii sułtańskiej i konieczność podjęcia wyczerpującego oblężenia. Nie był on jednak tylko, jak sugerują kronikarze osmańscy człowiekiem zbyt zadufanym w sobie i pysznym, w domyśle głupim i upartym. Widoczna przewa-

130 Por. Ustawa Sejmu Rzeczypospolitej Polskiej z dnia...2013 r., 1132-uchwała.doc-Sejm RP, http://aula.sejm. gov.ph/Druki7ka.nsf/ 0/.../File/1132-uchwała.doc. 
ga liczebna sił osmańskich stwarzała realną perspektywę poddania miasta, zwłaszcza, że wcale nie była pewna odsiecz w takiej formie i rozmiarach, jaka przybyła we wrześniu 1683 roku.

Przypisywany Kara Mustafie przez współczesnych XVII-wiecznych intelektualistów i pisarzy, czy poetów zamiar „ruszenia na Rzym” (owo „Czerwone Jabłko”) skończył się, na szczęście, wobec dalszego rozwoju wydarzeń jedynie strachem, który znalazł odbicie w ówczesnej literaturze i publicystyce politycznej. Również wynikał wówczas z ogromnej obawy przed straszliwymi skutkami ekspansji tureckiej, która towarzyszyła wielu mieszkańcom chrześcijańskiej Europy, zwłaszcza od XVI wieku. Zostały one wzmocnione w roku 1683 dość realną wówczas perspektywą zdobycia Wiednia przez armię wielkiego wezyra i obawą przed dalszymi, spodziewanymi etapami wielkiej ofensywy przeciwko Zachodowi. Pojawiające się potem i obecnie, w pierwszych latach XXI wieku opinie o podobnym pomyśle, są obecnie kolejnym elementem wzmożenia „nastroju zagrożenia” przed islamem w literaturze pięknej i w filmie. Mimo groźnych zapowiedzi samego wielkiego wezyra, czy wielkiego zamysłu, tkwiącego w samej ideologii osmańskiego ekspansjonizmu, przeszkodą były twarde realia. W rzeczywistości, armia osmańska, nawet przy założeniu, że Wiedeń zostanie zdobyty, nie była w stanie „natychmiast” ruszyć na Italię (a tym bardziej zdobyć Rzymu) w szybkim czasie, ani z uwagi na posiadane środki, czy wreszcie, trudne do pokonania w ówczesnych uwarunkowaniach trudności logistyczne i aprowizacyjne.

- Brak dostatecznej ilości ciężkich dział oblężniczych (bałjemezów) i kolubryn nie odbierał całkowicie zwycięstwa Kara Mustafie z uwagi na obecność doskonałych inżynierów tureckich, mających wiedzę na temat prowadzenia działań oblężniczych i znaczną liczbę minerów i artylerzystów. Innymi słowy, ów brak ciężkich bałjemezówi innych typów, mógł jedynie odsunąć zdobycie habsburskiej stolicy w czasie, bo postępy w działaniach oblężniczych rekompensowały z powodzeniem (mimo ponoszonych strat) podkładane miny i ładunki. Czy w ogóle armia nie miała tego typu armat? Tylko kronikarz Silahdar Mehmed aga pisze o ich zupełnym braku, bo już Husein Hezarfenn i Defterdar Sary Mehmed pasza wspominają o jakiejś nieznanej liczbie ciężkich dział-bałjemezów, które zostały użyte podczas oblężenia. Podobnie jak wcześniej sułtan Sulejman II, który także nie zabrał ze sobą armat o odpowiednim wagomiarze, Kara Mustafa liczył na efekt psychologiczny wynikający z samego faktu pojawienia się wielkiej armii tureckiej pod Wiedniem i przekonaniu o braku realnej możliwości znaczącej odsieczy z Rzeszy. Kompletnie osmański wódz nie liczył się także z pojawieniem ponad 20-tysięcznych sił Jana III, tak szybkim tempem ich koncentracji i jeszcze szybszym, bo 10-dniowym marszem z południa Rzeczypospolitej na teren Austrii.

- Twierdzenia ukraińskiego historyka, Tarasa Czuchłyba, o bardzo istotnej roli wojsk „ukraińskich” w odsieczy 1683 roku, czy nawet w domyśle, ewentualne szukanie przez niego iunctim z późniejszymi „Ukraińcami”, jak udowodnił Radosław Sikora (i inni historycy) jest jedynie asumptem do kreacji kolejnego mitu, nie mającego rzeczywistych podstaw naukowych. 
- Podawane przez niektórych XVII-wiecznych, cytowanych wyżej autorów, liczby ponad „200 tysięcy Turków” pod murami Wiednia, są dość przesadzone. Znacznie bliższe prawdy są ustalenia Jana Wimmera, Zbigniewa Wójcika, Otto Forsta de Battaglii, Simona Millara, oscylujące między 140/60, a 115 tysiącami sił armii Kara Mustafy na samym początku wyprawy. Ten pułap został potem osłabiony przez wydzielenie sił oblegających Jawaryn, korpusu wspierającego kuruców na północ od Dunaju (np. Preszburg) i same straty w ludziach wynikające z przedłużającego się oblężenia. Podczas prób zatrzymania wojsk przybyłych z odsieczą w dniach 11-12 września, na polu bitwy efektywnie walczyło już znacznie mniej Osmanów, bo nieco ponad 70 tysięcy (50-60 tys. bezpośrednio, około 20 tys. nadal prowadziło oblężenie), co było porównywalne z rozmiarami wojsk koalicji chrześcijańskiej.

- Wymieniana obecnie liczba „300 tysięcy Turków pod Wiedniem” jest jedynie dodatkowym elementem filmowej promocji obrazu w reżyserii Renzo Martinellego „Bitwa pod Wiedniem” (2012) i jest niekiedy bezkrytycznie powtarzana w mediach, jednak bez znajomości źródeł, czy fachowej literatury problemu. Jednak ta informacja, podobnie jak i inne, często nieprawdziwe, lub będące jedynie pomysłem scenarzysty, mają dziś znaczną szansę, by ulec utrwaleniu w świadomości potocznej, z racji tego, że wspomniany film we fragmentach jest wykorzystywany w polskich szkołach jako pomoc dydaktyczna.

- Opisując oblężenie Wiednia, znaczna część autorów marginalizuje działania wojsk Karola Lotaryńskiego oraz towarzyszących mu sił Hieronima Lubomirskiego, wagę bitew pod Preszburgiem i Bisambergiem, bądź niemal zupełnie je pomija. Zwycięstwa nad siłami tureckimi i kurucami na terenie Górnych Węgier dały istotny efekt psychologiczny dla wzmocnienia morale i wolę oporu załodze Wiednia. Poza tym, były one bardzo istotną częścią znacznie szerszych operacyjnie działań „bitwy pod Wiedniem”. Ewentualna klęska wojsk habsburskich oznaczałaby wydatne wzmocnienie pozycji Emeryka Thőkőlyego na terenie Górnych Węgier i poza tym obecność Turków u południowych rubieży Rzeczypospolitej.

- Zastrzeżenia na temat celowości i sensu polskiego wsparcia dla Habsburgów pod Wiedniem zostały omówione wyżej. $Z$ uwagi na zaistniałą sytuację i uwarunkowania, decyzja Jana III o odsieczy była jak najbardziej zasadna. Czy potrzebne natomiast były późniejsze polskie działania, tj. Parkany i Ostrzyhom, które także otworzyły Austriakom drogę dla zajęcia osmańskiej części Węgier? To pytanie pozostaje do dziś otwarte. 


\title{
ABOUT SOME MYTHS, INACCURACIES AND CONTROVERSIES CONCERNING THE TURKISH EXPEDITION TO VIENNA (1683)
}

\author{
DARIUSZ WYBRANOWSKI
}

Summary

In this article the author has analysed some myths, controversies and inaccuracies concerning the genesis, course and results of the armed expedition by Grand Vizier Kara Mustapha Pasha against Vienna in 1683. Some of them came into existence almost immediately after the victory at Vienna John III Sobieski, others were created or retained for various reasons? later, especially in the Polish literature of the subject. A part of them, for example the question of Ottoman Army of 300000 came into being only in our times under the influence of the film "The Day of Siege: September 12th 1683" (2012) directed by Renzo Martinelli. The problem of the more realistic assessment of the proportion of strength of the Ottoman and Christian armies is also considered by the author.

One of the main purposes of this publication is also the analysis of the media and film image of the Battle of Vienna and the place of the Battle in the Polish curriculum?? in our times as among others, a factor and a reason for creating new myths and inaccuracies connected with it. The article is an attempt to answer some research questions and some hypotheses on the basis of such written sources asthe Turkish chronicles and the available literature of the subject.The author makes an attempt to establish the main aim of the expedition and the personal responsibility of Grand Vizier for making a decision to change the direction of the expedition. One of the main themes analysed in the publication is a dispute about the adequate preparations of the Turkish army to besiege Vienna. I deal with the problem of the presence or absence of a heavy siege artillery, and the rationale behind the way the Turkish army conducted its military actions

Therefore, did the Grand Vizier expect resistance, how were his forces prepared the capture the capital of the Habsburg, or what factors did influence his operations? One of the problems discussed in this text, is Kara Mustapha's real potential, and quite controversial "expedition against Rome" after the possible capturing Vienna as the aim of the Ottoman ideology. The next part of the article I discuss the issue of appropriateness of the John III Sobieski's decision to hasten to the relief of the besieged Vienna. This problem has been as an object of disputes and polemics, in the 21th Century. The author views the Battle of Vienna not only as an armed clash of in a local geographic context, but also as a bigger military operation which took place in the Upper Hungary (present Slovakia),included the Battle of Pressburg (present Bratislava) and the Battle of Bisamberg near Vienna. I aim to show the importance of these facts for the victory at Vienna as well. 
